\title{
Tulane
}

\author{
Tulane Economics Working Paper Series
}

\section{Do State Fiscal Policies Affect State Economic Growth?}

\author{
James Alm \\ Department of Economics \\ Tulane University \\ New Orleans, LA \\ jalm@tulane.edu
}

\author{
Janet Rogers \\ Department of Planning Section \\ Division of Budget \& Planning \\ Nevada Department of Administration \\ Carson City, Nevada \\ jrogers@budget.state.nv.us
}

Working Paper 1107

April 2011

\begin{abstract}
What factors influence state economic growth? This paper uses annual state (and local) data for the years 1947 to 1997 for the 48 contiguous states to estimate the effects of a large number of factors, including taxation and expenditure policies, on state economic growth. A special feature of the empirical work is the use of orthogonal distance regression (ODR) to deal with the likely presence of measurement error in many of the variables. The results indicate that the correlation between state (and state and local) taxation policies is often statistically significant but also quite sensitive to the specific regressor set and time period; in contrast, the effects of expenditure policies are much more consistent. Of some interest, there is moderately strong evidence that a states political orientation has consistent and measurable effects on economic growth; perhaps surprisingly, a more "conservative" political orientation is associated with lower rates of economic growth. Finally, correction for measurement error is essential in estimating the growth impacts of policies. Indeed, when measurement error is considered via ODR estimation, the estimation results do not support conditional convergence in state per capita income.
\end{abstract}

Keywords: fiscal policies, regional economic growth, orthogonal distance regression JEL: H2, H7, O1, O4, R1, R5 


\title{
Do State Fiscal Policies Affect State Economic Growth?
}

\author{
James Alm and Janet Rogers
}

\begin{abstract}
What factors influence state economic growth? This paper uses annual state (and local) data for the years 1947 to 1997 for the 48 contiguous states to estimate the effects of a large number of factors, including taxation and expenditure policies, on state economic growth. A special feature of the empirical work is the use of orthogonal distance regression (ODR) to deal with the likely presence of measurement error in many of the variables. The results indicate that the correlation between state (and state and local) taxation policies is often statistically significant but also quite sensitive to the specific regressor set and time period; in contrast, the effects of expenditure policies are much more consistent. Of some interest, there is moderately strong evidence that a state's political orientation has consistent and measurable effects on economic growth; perhaps surprisingly, a more "conservative" political orientation is associated with lower rates of economic growth. Finally, correction for measurement error is essential in estimating the growth impacts of policies. Indeed, when measurement error is considered via ODR estimation, the estimation results do not support conditional convergence in state per capita income.
\end{abstract}

JEL Classification: $\mathrm{H} 2, \mathrm{H} 7, \mathrm{O} 1, \mathrm{O} 4, \mathrm{R} 1, \mathrm{R} 5$.

Keywords: Fiscal Policies, Regional Economic Growth, Orthogonal Distance Regression. 


\section{Introduction}

The average annual growth rates of per capita income for the individual 48 contiguous U.S. states over the last half of the twentieth century range from 1.73 percent to 3.15 percent. Six states have annual growth rates that exceed the national growth rate by more one-half of a percentage point at least half the time. Another four states have annual growth rates that are more than one-half of a percentage point less than the national growth rate at least half the time. Figure 1 identifies the states with the highest and the lowest average growth rates.

Why is this issue important? In 1947 the median real value of per capita income for the 48 contiguous states was just under $\$ 7,500$ (in 1997 dollars). If, over the 50 year period from 1947 to 1997 the annual growth rate had been 1.73 percent - the smallest average state growth rate observed for the period - then the median 1947 value of real per capita income would have increased to approximately $\$ 17,700$, or by nearly 235 percent. In contrast, if the annual growth rate had been 3.15 percent (or the highest observed average growth rate), then this same initial income would have increased by more than 470 percent, to $\$ 35,400$. Small changes in growth rates compound over 50 years to very large differences in per capita incomes. It is therefore imperative to understand the processes that cause the individual states to show such variations in their annual growth rates.

Many factors that influence economic growth, such as climate, proximity to national markets, and energy costs, cannot be changed by state (or national) government policy. Still other factors like labor force skills can only be changed by government in the long run. This leaves fiscal policies - tax and expenditures - as one of the primary means (along with regulations and legal considerations) available to state governments for accelerating economic growth in the short run. 
The purpose of this paper is to quantify the effects of various tax and expenditure policies on state per capita income growth, in order to determine whether there are public policies that foster higher or lower growth rates. We use annual state (and local) data for the years 1947 to 1997 for the 48 contiguous states to estimate the effects of a wide variety of factors, including taxation and expenditure policies, on state economic growth. A special feature of our empirical work is the use of orthogonal distance regression (ODR) to deal with the likely presence of measurement error in some variables. Our contributions are several: we examine a longer period of time than most other studies, we include a more comprehensive collection of explanatory variables, and our use of ODR methods allows us to address the measurement errors that are inherent in empirical growth studies.

Our results indicate that state economic policies matter, but not always in ways suggested by some previous work. For example, the correlation between state (and state and local) taxation policies is often statistically significant but is also quite sensitive to the specific regressor set and time period. In contrast, the effects of expenditure policies are much more consistent. Of some interest also, there is moderately strong evidence that a state's political orientation, as indicated by such variables as the political party of the governor and the presence of tax and expenditure limitations, has consistent and measurable effects on per capita income growth rates. Perhaps surprisingly, a more "conservative" political orientation is associated with lower rates of economic growth. Finally, although traditional estimation methods suggest conditional convergence in state per capita income, our ODR results that correct for measurement error do not support convergence. 
In the next section we briefly discuss the economic growth literature. In section 3 we present our empirical strategy, and we also discuss our data. We then discuss our estimation results. In section 5, we summarize our main results and their implications.

\section{A Selective Review of the Economic Growth Literature}

Building upon the exogenous growth models of Solow (1956) and Swan (1956), and the endogenous growth models of Romer $(1987,1990)$ and Barro and Sala-i-Martin (1992), among others, there are many empirical studies that attempt to estimate the determinates of economic growth. Many of these studies examine the growth experience at the country level (e.g., the "cross-country approach"). Of more relevance here, some work has focused on the growth experiences of the U.S. states (the "cross-region approach"). See Weil (2005) for a recent survey of much of this literature.

The standard approach begins by defining the relationship between per capita income in successive periods as:

$$
\mathrm{y}_{\mathrm{s}, \mathrm{t}+1}=\mathrm{y}_{\mathrm{s}, \mathrm{t}}\left(1+\mathrm{g}_{\mathrm{s}, \mathrm{t}}\right),
$$

where $y_{s, t}$ is per capita income of state $s$ in period $t$ (and similarly for period $t+1$ ) and $g_{s, t}$ is the growth rate of per capita income of state $s$ over the period $t$ to period $t+1$. Applying a logarithmic transformation to equation (1), a linear regression model is obtained as:

$$
\mathrm{g}_{\mathrm{s}, \mathrm{t}}=\beta_{\mathrm{x}} \mathrm{x}_{\mathrm{s}, \mathrm{t}}+\varepsilon_{\gamma \mathrm{s}, \mathrm{t}},
$$

where $\mathrm{x}_{\mathrm{s}, \mathrm{t}}$ is a vector of explanatory variables for state $\mathrm{s}$ in period $\mathrm{t}$ (including regional and geographic characteristics of state $\mathrm{s}$ that are constant over time, national characteristics in year $t$ that do not vary by state, and other variables that vary both by state $s$ and year t), $\beta_{\mathrm{x}}$ is a vector of 
coefficients, and $\varepsilon_{\gamma \mathrm{s}, \mathrm{t}}$ is the model error term for state $\mathrm{s}$ in period t. Equation (2) is then estimated by various estimation methods, typically ordinary linear least squares (LLS) methods. Researchers have used a wide range of explanatory variables in their cross-regional studies. For example, Canto and Webb (1987) present a non-pooled regression of cross-region annual U.S. data for the period 1957 through 1977. Their independent variable is the average state growth rate, and explanatory variables include the U.S. growth rate, the difference between the state's government purchases and the average of all states' government purchases, the difference between the state's transfer payments and the average of all states' transfer payments, and the difference between the state's relative tax burden and the average of all states' relative tax burden. Similarly, Coughlin and Mandelbaum (1989) compare U.S. state per capita incomes as a percent of average state per capita income and overall state income inequality with regional variables that indicate coastal, energy-production, sun-belt, and "farm-crises" states. Barro and Sala-i-Martin (1991) examine cross-region data for the U.S. states using various sub-intervals for the period 1840 through 1985 . They regress the average growth rate against initial income, three regional specifications (South, Midwest, West), and employment composition for nine industrial sectors. For some other cross-region studies, see Berry and Kaserman (1987), Mofidi and Stone (1990), Yu, Wallace, and Nardinelli (1991), Mullen and Williams (1994), and Phillips and Goss (1995). More recently, Crain and Lee (1999), Caselli and Coleman (2001), Akai and Sakata (2002), Garofalo and Yamarik (2002), and Tomljanovich (2004), and Holcombe and Lacombe (2004) conduct similar analyses, with quite mixed results. In perhaps the most comprehensive work to date, Reed (2008a, 2008b) uses five-year data from 1970 to 1999 for the 48 continental states, and finds a significant negative relationship between taxes and state economic growth across a wide range of specifications and estimation procedures. 
These growth regressions have produced a variety of results, and only modest consistency. A similar lack of consensus exists in cross-country growth regressions. In a survey of this latter work, Levine and Renelt (1992) quantify whether the conclusions from crosscountry studies are robust or fragile when there are small changes to the conditioning information set. Using the extreme bounds analysis of Leamer $(1983,1985)$, they find that the estimation results are quite fragile. Sala-i-Martin, Doppelhofer, and Miller (2004) report somewhat more optimistic results in cross-country studies by examining an approximation to the cumulative distribution function of the estimators. Even so, their results find that only 18 out of 67 explanatory variables (or only 27 percent) are robustly correlated with measures of economic growth. Crain and Lee (1999) report similar results for cross-region analysis of U.S. states.

As for the more specific impact of fiscal policies, the generally held presumption is that higher taxes tend to lower economic growth because of their distortionary effects, because they tend to discourage the creation of new firms and jobs, and because they inhibit investment. For example, it is widely held that higher income taxes will lower the rate of growth because they lower the net return to private investment and make investment activities less attractive. Even so, there is at least some recognition that the government expenditures financed by tax revenues might provide superior public services, thereby making a higher-tax area more, not less, attractive. For example, high public spending on infrastructure investment (e.g., transportation, communications, education) is generally believed to increase growth rates. Indeed, Mofidi and Stone (1990) find that state economic performance depends upon the interrelationship between state taxes and the programs upon which the taxes are spent. They also find that state and local taxes have a negative effect on growth when the revenues are devoted to transfer payments, but that expenditures on health, education, and public infrastructure have positive effects on growth. 
It should also be noted that public sector "institutions" are also likely to affect economic growth. For example, Persson and Tabellini (1992) outline a theory that relates different political incentives and political institutions to growth. They conclude that income inequality is "bad" for growth in democracies, while land concentration is bad for growth everywhere. Relatedly, there is much empirical work that suggests that factors such as the number of local governments, the presence of tax and expenditure limitations (TELs), and the political composition of the governing party affect (and are in turn affected by) fiscal policies.

In sum, existing results for the effects of fiscal policies on state economic growth are quite variable. The next section presents our approach to estimating the impacts of fiscal (and other) factors on economic growth.

\section{Methods, Data, and Specifications}

\subsection{Methods}

The specification of growth regression models is complicated by the likelihood that the observed value of per capita income in state $\mathrm{s}$ in year $\mathrm{t}\left(\mathrm{y}_{\mathrm{s}, \mathrm{t}}\right)$ includes an unknown and unknowable measurement error $\varepsilon_{\mathrm{ys}, \mathrm{t}}$; that is, $\varepsilon_{\mathrm{ys}, \mathrm{t}}$ denotes any random disturbance in the observed value of per capita income, so that observed $\mathrm{y}_{\mathrm{s}, \mathrm{t}}$ is related to "true" $\mathrm{y}_{\mathrm{s}, \mathrm{t}}^{\tau}$ by the relationship:

$$
\mathrm{y}_{\mathrm{s}, \mathrm{t}}=\mathrm{y}_{\mathrm{s}, \mathrm{t}}^{\tau}+\varepsilon_{\mathrm{y}, \mathrm{t}},
$$

where the superscript $\tau$ denotes the true but unobservable value that excludes all measurement errors. Consequently, the error term in the resulting growth regression consists of a combination of the error term associated with the model $\varepsilon_{\gamma \mathrm{s}, \mathrm{t}}$ and the error term associated with the 
measurement error in per capita income $\varepsilon_{\mathrm{ys}, \mathrm{t}}$ (which also includes the measurement error in the initial period income, or $\left.\varepsilon_{\mathrm{y} \mathrm{s}, \mathrm{t}}\right)$.

The measurement errors in per capita income arise from several sources. First, reliable measures of price levels or price indices are not always available for individual states for an extended time period; however, see Berry, Fording, and Hanson (2000). The use of the national price index, as is employed in all analyses here, could potentially introduce two types of measurement error: if relative purchasing power parity does not hold across the states, then the growth rates of real per capita income are mismeasured; and, if absolute purchasing power parity does not hold, then the levels of real per capita income are mismeasured. Second, per capita values are computed from population values that are likely measured with error. Third, state income should be adjusted for the net inflow of the earnings of wage and salary workers who are interstate commuters, and in this adjustment additional errors are likely introduced.

There is a large econometric literature on measurement errors and the associated errorsin-variables problem. Work that addresses measurement errors in economic growth regressions is much sparser (DeLong 1988; Barro and Sala-i-Martin 1991). Ordinary linear or nonlinear least squares estimation does not address measurement error issues. In contrast, our preferred estimation method corrects for measurement error, and, in the process, generates significant improvements in the estimates.

In particular, ordinary least squares methods are inappropriate in the presence of errorsin-variables. When suitable instruments that are correlated with the explanatory variables but uncorrelated with the error terms can be found, the method of instrumental variables is often used when such errors are present. Another procedure is orthogonal distance regression (ODR), 
which is especially appropriate when the statistical model is nonlinear in the unknown variables and when there is some information available about the variance of the measurement error $\left(\varepsilon_{\mathrm{ys}, \mathrm{t}}\right)$ (including $\left.\mathrm{t}_{0}\right)$ and the size relative to the model error $\left(\varepsilon_{\gamma_{\mathrm{s}, \mathrm{t}}}\right)$. While information about the variances is not always readily available, it is often reasonable to assume that the standard deviation of the measurement error is the same for all $\mathrm{s}$ and $\mathrm{t}$ (including $\mathrm{t}_{0}$ ), and that the standard deviation of the model error is also constant over all $\mathrm{s}$ and $\mathrm{t}$. Therefore, it is only necessary to make assumptions about the magnitude of the ratio of the standard deviations to obtain the ODR solution.

More precisely, if we assume that the measurement error $\left(\varepsilon_{\mathrm{y}, \mathrm{t}}\right)$ and the model error $\left(\varepsilon_{\gamma, t}\right)$ in the observation corresponding to state s are independent between observations $t_{i}$ and $t_{j}$, for $i \neq j$, and have known (relative) variance, then we can derive the distribution of the combined error $\varepsilon_{\mathrm{s}}=\left[\varepsilon_{\mathrm{ys}, \mathrm{t}} ; \varepsilon_{\gamma \mathrm{s}, \mathrm{t}}\right]$ for any state s as $N\left(0, \boldsymbol{\Omega}_{\varepsilon \mathrm{s}}\right)$, where 0 denotes a conformably dimensioned array of zeros and $\boldsymbol{\Omega}_{\varepsilon \text { s }}$ denotes the covariance matrix for all model and measurement errors associated with state $\mathrm{s}$. As a result, asymptotically maximum likelihood estimators can be obtained employing ODR. Unlike LLS methods, which minimize the sum of the squared vertical deviations between the dependent variable and the fitted "line", ODR methods minimize the orthogonal (or perpendicular) deviations from the fitted line. See Boggs, Bryd, and Schnabel (1987) and Boggs, Donaldson, Schnabel, and Spiegelman (1988) for detailed discussions of ODR methods, including an algorithm that can be used to calculate ODR coefficient estimates. In fact, we use weighted ODR methods, which allow for heteroscedastic variances within and between and observations, for nonzero covariances within observations (even though covariances between observations are identically zero), and for nonlinearity in the explanatory variables and/or the estimated coefficients. 
Monte Carlo experiments that we have conducted show that measurement errors do in fact significantly affect LLS estimates from growth regressions. These experiments also show that ODR methods noticeably improve bias and mean square error results, even when the assumptions imposed on the solution are wrong. In particular, the results show that LLS estimates designed to test the "convergence hypothesis" have a strong tendency to be more negatively biased than the same coefficient estimated using ODR methods. Furthermore, for all but one of the more than 80 pairs of median bias examined in our Monte Carlo study, the bias in the LLS estimator is larger than that in the ODR estimator by more than a factor of 2 . These experiments demonstrate that the measurement errors inherent in growth regression data are important, and should be considered explicitly when attempting to analyze the factors that affect economic growth. All of our Monte Carlo results are available upon request.

\subsection{Data}

Response Variable. The response variable in our basic specifications is the annual growth rate in per capita personal income for the 48 contiguous states over the period 1947 to 1997. Personal income is computed by the U.S. Department of Commerce Bureau of Economic Analysis as the sum of wages and salaries, other labor income, proprietors' income, dividends, interest, rent, and transfer payments, less personal contributions for social insurance. The main difference between state personal income and gross state product involves the treatment of capital income. Personal income includes corporate net income only when individuals receive payment as dividends; gross state product includes corporate profits and depreciation. Also, gross state product attributes capital income to the state in which the business activity occurs, while personal income attributes capital income to the state of the asset holder. Neither measure includes capital gains. 
The personal income of a state is defined as the income received by the residents of the state. However, the estimates of wages and salaries, other labor income, and personal contributions for social insurance are based mainly on source data that are reported by place of work, not by place of residence. Accordingly, an adjustment for residence, equal to the net inflow of the earnings of wage and salary workers who are interstate commuters, must be estimated so that the place-of-residence measures of earnings and personal income can be derived. Descriptive statistics for the resulting growth rates in per capita income data are provided in Table 1.

Explanatory Variables. We have assembled more than 130 explanatory variables for the analysis. These variables can be grouped into five categories: revenues, expenditures, demographics, geographics, and national. The first three categories include values that vary by state and by year; the fourth includes values that vary by state but not by year; and the fifth includes values that vary by year but not by state. All variables in each category are identified in Tables 2 through 6 . Note that the first two letters of each variable name denote the category (e.g., rv for revenues, sp for spending or expenditures, dm for demographics, ge for geographics, and us for national).

The revenue and expenditure variables are of obvious interest to policy makers. The various tax sources (e.g., individual or corporate income, sales, and property taxes) have implications for the returns to individuals and firms from their activities. Similarly, how a state chooses to spend these revenues is also important. For example, expenditures on education can have a direct impact on growth by producing a more capable work force, and are also likely to have an indirect effect related to the perception of the importance that the state places on education. 
The revenue, expenditure, demographic, and geographic variables have been recorded at a relatively fine level of detail. Composite variables have then been constructed from these values. For example, the data include values for general and select sales taxes (variables rvTXSALgen and rvTXSALsel, respectively), as well as total sales taxes (variable rvTXSALtot) computed from their sum. Similarly, the geographic category includes dummy variables to indicate natural resources in the state (such as variables geMNau, geMNfe, and geMNcoal), as well as a dummy variable to indicate the occurrence of one or more of these resources (variable geMN). The revenue and expenditure variables are included either as per capita values, as a percent of per capita income, or as a percent of total tax revenue. All explanatory variables are lagged one year.

Annual values for state revenues and expenditures, as well as for all demographic, geographic, and national variables, are available for the period 1947 through 1997. Annual estimates for total state p/us loca/ revenues and expenditures are not recorded prior to 1959 (and not all variables are available until 1977); as a result, our combined state and local analysis is for the shorter periods 1959 to 1997 (and 1977 to 1997). The data are obtained from various issues of the Book of the States, the Statistical Abstract of the United States, Current Population Reports (Series P60), State Government Finances reports, and the World Almanac; some variables are obtained from personal communication with staff at the U.S. Bureau of the Census. The primary source for the estimates of total earnings and employment by place of work is the ES-202 series from the U.S. Bureau of Labor Statistics.

\subsection{Specifications}

Baseline Regression. Levine and Renelt (1992), Sala-i-Martin (1997), Crain and Lee (1999), and others have explored the sensitivity of regression results by comparing outcomes 
against the results from a set of "core" variables. However, there is little agreement on which variables should be included in the core set of regressors. For example, Levine and Renelt (1992) use the investment share of gross domestic product (GDP), the initial level of real GDP per capita, the initial secondary-school enrollment rate, and the average annual rate of population growth as the core variables in their cross-country analysis. Sala-i-Martin (1997) uses the level of income, life expectancy, and primary-school enrollment rate as the core variables for his cross-country sensitivity analysis.

In our work, we choose a set of six core regressors, and our baseline regression (denoted Regression $A$ ) includes only these variables. These core regressors are:

- usGRW: the U.S. per capita income growth rate

- usINF: the U.S. inflation rate

- usFUELpp: the average U.S. producer price of fuels

- gePOLstate: a dummy variable equal to 1 if statehood was attained before 1800 , and 0 otherwise

- geREGcon: a dummy variable indicating whether the state is one of the contiguous 48 states (e.g., the constant term in the regression)

- $\mathrm{y}_{\mathrm{s}, \mathrm{t} 0}$ : the value of per capita income for state $\mathrm{s}$ in year $\mathrm{t}_{0}$.

These variables are selected for several reasons. The value of per capita income for state $\mathrm{s}$ in year $\mathrm{t}_{0}\left(\mathrm{y}_{\mathrm{s}, \mathrm{t}}\right)$ is typically included in growth regressions to test the convergence hypothesis, or the notion that a state with a lower initial level of per capita income will experience a higher growth rate. If states experience convergence, then the sign of the estimated coefficient would be negative. The geographic variable gePOLstate designates the "age" of the states, old versus new, and could account for differences in growth rates due to the "maturity" of the state. The other geographic variable (or geREGcon) is the constant term of the regression.

The remaining three core variables are national variables. The variable usGRW specifies the annual real U.S. per capita income growth rate. It is well-known that growth equations may be seriously affected by omitted variables. To the extent that state per capita income growth 
rates respond to the same shocks and stimuli as the U.S. growth rate, this variable provides some protection against omitted variable bias. It should also account for much of the business cycle component of the states' growth rates. Since individual state economies are small relative to the U.S. economy as a whole, usGRW is exogenous. Its coefficient is expected to be roughly one.

The regressor usINF is the national inflation rate, and its coefficient is expected to be negative because inflation is generally presumed to be harmful to economic growth. The variable usFUELpp, which denotes the average national producer price of fuels, is another exogenous variable intended to capture the effects of external (fuel) shocks to the U.S. economy.

The baseline regression is estimated for three time periods: 1947 to 1997,1959 to 1997 , and 1977 to 1997 . These correspond, respectively, to the longest period for which annual state data are available, the longest period for which state plus local total tax and property tax revenue and state and local expenditure values are available, and the longest period for which all state plus local tax and expenditure values have been recorded at a relatively fine level of detail. The results from the baseline regression are presented in Appendix Tables, and are discussed in section 4. All regressions correct for first order autocorrelation.

Beyond the Baseline Regression. In addition to the baseline regression, several other primary regression specifications are analyzed for the period 1959 to 1997, using each of three representations of the fiscal variables (value per capita, value as a percent of income, and value as a percent of total tax). These other primary specifications are denoted Regression $B$, Regression C, and Regression D.

Regression $B$ includes the six core variables plus 12 fiscal variables:

- $\quad$ rVTXTOTAL: the sum of all state plus local taxes

- rVTXINCcor: corporate income tax revenues

- rVTXINCind: individual income tax revenues (only available at the local level after 1977)

- rvTXSALgen: state level general sales tax revenues 
- rVTXPROP: the sum of state plus local property taxes

- rvTRFtot: the total amount of revenues transferred from the federal to the state government

- rVTRFedu: the amount of revenues earmarked for education that are transferred from the federal to the state government

- rVTRFhwy: the amount of revenues earmarked for highways that are transferred from the federal to the state government

- spEDUtot: the sum of state plus local expenditures for primary and secondary education, including capital construction

- spHWYtot: the sum of state plus local expenditures for highways, including capital construction

- spWELtot: the sum of state plus local expenditures for welfare

- spCAPhwy: the sum of state plus local expenditures for capital construction of highways.

(Remember that many of the tax variables are not available at the local level prior to 1977.) This set of variables is assembled to examine the impact of tax, transfer, general expenditure, and capital outlay variables. See Tables 2 and 3 for variable definitions.

Regression $C$ includes the six core variables from Regression $A$ plus the 12 fiscal variables included in Regression B, along with another 30 variables from the demographic, geographic, and national variable sets. This set of variables includes every variable in which anyone might reasonably have any interest, plus a few others thrown in for good measure. These variables are defined in Tables 4, 5, and 6 .

Regression D represents a subset of variables used in Regression C. It includes the 12 fiscal variables from Regression $B$, plus 13 variables selected on the basis of their explanatory power. These 13 variables are: dmPOLgov, dmTXref, dmTXsvl, dmPOP, dmDEN, dmWAGEcv, dmPRNFPcv, geHEtotP, geSIZ, geSIZPf, geREGatl, geREGpac, and gePOLCgov. We believe that this variable set is the most representative, and it is the one discussed in greatest detail in section 4 .

Finally, we have also estimated a wide variety of additional specifications. Regression $E$ uses the same regressors and time spans as Regression $D$, but excludes the five states with the 
highest variability of growth rates (Iowa, Montana, Nebraska, North Dakota, and South Dakota). Regression $F$ has the same explanatory variables and uses the same subset of states as Regression E, but the time span is 1977 to 1996 rather than 1959 to 1996 . Regression $G$ is the same as Regression F, except that total state plus local fiscal values are used for all tax and expenditure variables. We discuss summary results for these specifications later.

Aside from these specifications, it should be noted that we have estimated many additional specifications, including ones in which we examine alternative time periods, in which we include state plus local measures of all tax and expenditure variables, in which dummy variables for the presence (or absence) of specific tax instruments are used rather than their values, and in which the growth experience of two individual states (Colorado and Georgia) are examined separately. All results are available upon request.

\section{Results}

Estimation results from some basic specifications are presented in Appendix Tables A1 to A7; all other results are available upon request. The boxes included below summarize the outcomes from the regressions. Column headings within the boxes indicate the time period, the fiscal variable parameterization (e.g., per capita, percent of income, percent of total taxes), as well as the regression identifier (e.g., $A, B, C, D, E, F$, or $G$ ). The row headings indicate the construction of the fiscal variables: "asl" denotes that all fiscal variables are constructed using the sum of state plus local amounts, "psl" denotes that property taxes, total taxes, and expenditures values are constructed using the sum of state plus local amounts (while other revenue variables are composed of only state values), and "s" denotes that fiscal values are 
constructed using only state values. The individual box entries can be interpreted using the following "legend":

\begin{tabular}{|c|c|c|c|c|c|c|}
\hline Entry & Sign of Coefficient & \multicolumn{5}{|c|}{ Significance Level $(\alpha)$} \\
\hline-3 & Negative & $0 \%$ & $<$ & $\alpha$ & $\leq$ & $5 \%$ \\
\hline-2 & Negative & $5 \%$ & $<$ & $\alpha$ & $\leq$ & $10 \%$ \\
\hline-1 & Negative & $10 \%$ & $<$ & $\alpha$ & $\leq$ & $20 \%$ \\
\hline-0 & Negative & $20 \%$ & $<$ & $\alpha$ & $\leq$ & $100 \%$ \\
\hline+0 & Positive & $20 \%$ & $<$ & $\alpha$ & $\leq$ & $100 \%$ \\
\hline+1 & Positive & $10 \%$ & $<$ & $\alpha$ & $\leq$ & $20 \%$ \\
\hline+2 & Positive & $5 \%$ & $<$ & $\alpha$ & $\leq$ & $10 \%$ \\
\hline+3 & Positive & $0 \%$ & $<$ & $\alpha$ & $\leq$ & $5 \%$ \\
\hline
\end{tabular}

so that numbers +3 and +2 denote positive coefficients with statistical significance at accepted levels (as do -3 and -2 for negative coefficients with some statistical significance), while numbers $-1,-0,+0$, and +1 denote little statistical significance. Note that the Appendix Tables display the results for both ODR and LLS methods. In general, the coefficient estimates from the two methods are similar, but there are also some striking differences. In particular, nearly one-fourth of the coefficients estimated by the two methods have different signs. Further, for more than 30 percent of these cases, one or the other estimate is significant at conventional levels; for more than 20 percent of these cases, both estimated coefficients are significant at conventional levels, but the correlation of one coefficient is positive while the correlation of the other coefficient is negative. When the two methods produce significantly different coefficients, the Monte Carlo results discussed earlier indicate that the ODR coefficients are more likely to be reliable. For this reason, our discussion focuses on the ODR results. Note also that the constant term in the regressions (geREGcon) is generally positive and significant.

\subsection{Core Variables}

The coefficient of the U.S. per capita income growth rate (UsGRW) is positive and significantly different than zero (at the 95 percent confidence level) in every instance. The 
estimated value is roughly 0.9 , but it is significantly different than 1.0 in nearly all regressions, indicating that the individual states follow approximately the same growth pattern as the country as a whole and are responding individually to the same shocks and stimuli in roughly the same manner as the national economy.

\begin{tabular}{|c|c|c|c|c|c|c|c|c|c|c|c|c|c|}
\hline \multicolumn{14}{|c|}{ Variable: usGRW } \\
\hline \multirow[b]{2}{*}{ Year: $t_{0}$} & \multirow[b]{2}{*}{$A$} & \multicolumn{4}{|c|}{ Per Capita } & \multicolumn{4}{|c|}{ Percent of Income } & \multicolumn{4}{|c|}{ Percent of Total Tax } \\
\hline & & $B$ & C & $D$ & $E F G$ & $B$ & $C$ & $D$ & $E F G$ & $B$ & $c$ & $D$ & $E F G$ \\
\hline asl 1977 & +3 & & & & +3 & & & & +3 & & & & +3 \\
\hline psl 1977 & & & & & +3 & & & & +3 & & & & +3 \\
\hline 1959 & +3 & +3 & +3 & +3 & +3 & +3 & +3 & +3 & +3 & +3 & +3 & +3 & +3 \\
\hline $\begin{array}{ll}\text { s } 1959 \\
\end{array}$ & & & & & +3 & & & & +3 & & & & +3 \\
\hline 1947 & +3 & & & & +3 & & & & +3 & & & & +3 \\
\hline
\end{tabular}

For the U.S. inflation rate (usINF), our results indicate that higher inflation rates are significantly negatively correlated with per capita income growth in most specifications. The estimated coefficient suggests that a one percent increase in inflation is associated with lower per capita income growth of roughly one-quarter of a percentage point.

\begin{tabular}{|c|c|c|c|c|c|c|c|c|c|c|c|c|c|}
\hline \multicolumn{14}{|c|}{ Variable: usINF } \\
\hline & & \multicolumn{4}{|c|}{ Per Capita } & \multicolumn{4}{|c|}{ Percent of Income } & \multicolumn{4}{|c|}{ Percent of Total Tax } \\
\hline Year: $t_{0}$ & $A$ & $B$ & C & $D$ & $E F G$ & $B$ & $C$ & $D$ & $E F G$ & $B$ & $C$ & $D$ & $E F G$ \\
\hline asl 1977 & -0 & & & & -3 & & & & -3 & & & & -3 \\
\hline psl 1977 & & & & & -3 & & & & -3 & & & & -3 \\
\hline 1959 & +0 & -3 & -3 & -3 & -3 & -3 & -3 & -3 & -3 & -3 & -3 & -3 & -3 \\
\hline s 1959 & & & & & -3 & & & & -3 & & & & -3 \\
\hline 1947 & +3 & & & & -3 & & & & -3 & & & & -3 \\
\hline
\end{tabular}

Rising energy costs are generally thought to adversely affect economic growth. Our results consistently confirm this, with a negative and statistically significant coefficient on usFUELpp.

\begin{tabular}{|c|c|c|c|c|c|c|c|c|c|c|c|c|c|}
\hline \multicolumn{14}{|c|}{ Variable: usFUELpp } \\
\hline \multirow[b]{2}{*}{ Year: $t_{0}$} & & \multicolumn{4}{|c|}{ Per Capita } & \multicolumn{4}{|c|}{ Percent of Income } & \multicolumn{4}{|c|}{ Percent of Total Tax } \\
\hline & $A$ & $B$ & C & $D$ & $E F G$ & $B$ & $C$ & $D$ & $E F G$ & $B$ & $C$ & $D$ & $E F G$ \\
\hline asl 1977 & -3 & & & & -3 & & & & -3 & & & & -3 \\
\hline
\end{tabular}




\begin{tabular}{|c|c|c|c|c|c|c|c|c|c|c|c|c|c|}
\hline ps1 1977 & & & & & -3 & & & & -3 & & & & -3 \\
\hline 1959 & -3 & -3 & -3 & -3 & -3 & -3 & -3 & -3 & -3 & -3 & -3 & -3 & -3 \\
\hline s 1959 & & & & & -3 & & & & -3 & & & & -3 \\
\hline 1947 & -3 & & & & -3 & & & & -3 & & & & -3 \\
\hline
\end{tabular}

The dummy variable gePOLstate provides a simple designation of the "age" of the state, as determined by the year in which statehood was obtained. Values of 1 for gePOLstate identify states that acquired statehood prior to 1800 (e.g., "old" states), while values of 0 identify states that acquired statehood after 1800 (e.g., "young” states). The estimated coefficient for gePOLstate is always positive and statistically significant, indicating that older states have higher per capita income growth than younger states. This is a plausible result, and is consistent with the presence of more developed infrastructures in older states. However, this result is not consistent with convergence.

\begin{tabular}{|c|c|c|c|c|c|c|c|c|c|c|c|c|c|}
\hline \multicolumn{14}{|c|}{ Variable: gePOLstate } \\
\hline \multirow[b]{2}{*}{ Year: $t_{0}$} & & \multicolumn{4}{|c|}{ Per Capita } & \multicolumn{4}{|c|}{ Percent of Income } & \multicolumn{4}{|c|}{ Percent of Total Tax } \\
\hline & $A$ & $B$ & $C$ & $D$ & $E F G$ & $B$ & $C$ & $D$ & $E F G$ & $B$ & $C$ & $D$ & $E F G$ \\
\hline asl 1977 & +3 & & & & +3 & & & & +3 & & & & +3 \\
\hline psl 1977 & & & & & +3 & & & & +3 & & & & +3 \\
\hline 1959 & +3 & +3 & +3 & +3 & +3 & +3 & +3 & +3 & +3 & +3 & +3 & +3 & +3 \\
\hline s 1959 & & & & & +3 & & & & +3 & & & & +3 \\
\hline 1947 & +3 & & & & +3 & & & & +3 & & & & +3 \\
\hline
\end{tabular}

The neoclassical growth model asserts that, ceteris paribus, an economy with a lower initial income will grow faster than an economy with a higher initial income. However, in our results, initial income $\left(\mathrm{y}_{\mathrm{s}, \mathrm{t}}\right)$ has quite variable effects on the various specifications. When the explanatory variables include the full set of socio-economic regressors, our results provide little support for conditional convergence, and strong evidence of divergence after 1977.

When the coefficient on $\mathrm{y}_{\mathrm{s}, \mathrm{t}}$ is not significant at conventional levels, it might be argued that multicollinearity among the regressors is the problem. However, variance decomposition 
results indicate that this is unlikely. Moreover, our Monte Carlo experiments indicate that the measurement errors in per capita income have a significant and adverse effect on LLS results when annual data are employed. However, if annual data are not used, then the fiscal and policy variables that are being examined must be aggregated over the period between observations to obtain a single representative value, even though it is the effect of the variation of these fiscal and policy variables that we are seeking to measure. Hence, previously reported results of convergence are suspect either because they have not taken measurement errors into account, or because the fiscal and policy variables have been recorded in such a way that their effect on economic growth cannot be accurately determined. The ODR results reported here suffer from neither of these problems.

\begin{tabular}{|c|c|c|c|c|c|c|c|c|c|c|c|c|c|}
\hline \multicolumn{10}{|c|}{ Variable: $\mathrm{y}_{\mathrm{s}, \mathrm{to}}$} \\
\hline & & \multicolumn{10}{c|}{ Per Capita } & \multicolumn{3}{c|}{ Percent of Income } & \multicolumn{3}{c|}{ Percent of Total Tax } \\
\cline { 2 - 16 } Year: $\mathrm{t}_{0}$ & $A$ & $B$ & $C$ & $D$ & $E F G$ & $B$ & $C$ & $D$ & $E F G$ & $B$ & $C$ & $D$ & $E F G$ \\
\hline as1 1977 & -0 & & & & +3 & & & & +3 & & & & +3 \\
\hline ps1 1977 & & & & & +3 & & & & +3 & & & & +3 \\
\hline 1959 & -3 & -3 & +3 & +3 & +3 & -3 & +0 & +0 & +0 & -3 & -0 & +0 & +0 \\
\hline s 1959 & & & & & -0 & & & & -0 & & & & -0 \\
\hline 1947 & -3 & & & & +0 & & & & -1 & & & & -0 \\
\hline
\end{tabular}

In sum, the analysis of the core variables identifies strong correlations where they are expected. The only surprising result is that for initial income, which indicates divergence from 1977 to the present.

\subsection{Fiscal Variables}

The variable rVTXTOTAL (expressed as real dollars per capita or as a percent of total state income) includes all tax revenues but excludes transfers from the federal government. The estimated coefficient on rVTXTOTAL is quite sensitive to the other variables that are included and also to the specific measures of tax and other fiscal variables; in additional specifications that are 
not reported here, the coefficient is also sensitive to the period of the estimation. Depending on the parameterization and the starting year, the coefficient is sometimes significantly negative, sometimes significantly positive, and sometimes not significant at all. It therefore appears that total tax revenue is not a very robust indicator of economic growth. The most consistent results are observed when rVTXTOTAL is represented as a percent of income and the other fiscal variables are presented as a percent of total taxes; in these cases, the coefficient for rVTXTOTAL is always negative and significant at the 95 percent confidence level.

\begin{tabular}{|c|c|c|c|c|c|c|c|c|}
\hline \multicolumn{7}{|c|}{ Variable: rvTXTOTAL } \\
\hline \multirow{2}{*}{ Year: $\mathrm{t}_{0}$} & $B$ & $C$ & $D$ & $E F G$ & $B$ & $C$ & $D$ & $E F G$ \\
\hline asl 1977 & & & & -3 & & & & -3 \\
\hline ps1 1977 & & & & -3 & & & & -1 \\
\hline 1959 & +1 & -0 & +0 & +0 & -0 & -0 & -0 & -0 \\
\hline s 1959 & & & & +0 & & & & +0 \\
\hline \multicolumn{1}{|c|}{1947} & & & & +0 & & & & +0 \\
\hline
\end{tabular}

Corporate income taxation (rvTXINCcor) is represented as a per capita amount, as a percent of income, or as a percent of total tax revenue. It might be expected that greater reliance on the corporate income tax would have a negative effect on economic growth. However, the coefficient on rvTXINCcor is never significantly negative, and is frequently significantly positive at conventional levels, especially in regressions $E, F$, and $G$.

\begin{tabular}{|r|c|c|c|c|c|c|c|c|c|c|c|c|}
\hline \multicolumn{10}{|c|}{ Variable: rvTXINCcor } \\
\hline \multirow{2}{*}{ Year: $\mathrm{t}_{0}$} & $B$ & $C$ & $D$ & $E F G$ & $B$ & $C$ & $D$ & $E F G$ & $B$ & $C$ & $D$ & $E F G$ \\
\hline asl 1977 & & & & +3 & & & & +3 & & & & +1 \\
\hline ps1 1977 & & & & +1 & & & & +2 & & & & +0 \\
\hline 1959 & +0 & +0 & +0 & +3 & +0 & +1 & +0 & +3 & +0 & +1 & +1 & +2 \\
\hline s 1959 & & & & +1 & & & & +2 & & & & +0 \\
\hline 1947 & & & & +0 & & & & +0 & & & & -0 \\
\hline
\end{tabular}


Similar results are found for the individual income tax variable (rvTXINCind). The estimated coefficient is never significantly negative at conventional levels, but its coefficient is often significantly positive.

\begin{tabular}{|r|c|c|c|c|c|c|c|c|c|c|c|c|}
\hline \multicolumn{10}{|c|}{ Variable: rvTXINCind } \\
\hline \multirow{2}{*}{ Year: $\mathrm{t}_{0}$} & \multicolumn{10}{|c|}{ Per Capita } & \multicolumn{3}{|c|}{ Percent of Income } & \multicolumn{3}{|c|}{ Percent of Total Tax } \\
\hline & $B$ & $C$ & $D$ & $E F G$ & $B$ & $C$ & $D$ & $E F G$ & $B$ & $C$ & $D$ & $E F G$ \\
\hline asl 1977 & & & & +3 & & & & +3 & & & & +3 \\
\hline ps1 1977 & & & & +3 & & & & +3 & & & & +1 \\
\hline 1959 & +0 & +3 & +3 & +3 & +0 & +1 & +1 & +1 & +0 & +1 & +1 & +0 \\
\hline s 1959 & & & & +2 & & & & +0 & & & & +0 \\
\hline 1947 & & & & +1 & & & & +0 & & & & +0 \\
\hline
\end{tabular}

Not all states impose a general sales tax (rvTXSALgen). Even so, the coefficients are generally positive, though not always statistically significant.

\begin{tabular}{|c|c|c|c|c|c|c|c|c|c|c|c|c|}
\hline \multicolumn{13}{|c|}{ Variable: rvTXSALgen } \\
\hline \multirow[b]{2}{*}{ Year: $t_{0}$} & \multicolumn{4}{|c|}{ Per Capita } & \multicolumn{4}{|c|}{ Percent of Income } & \multicolumn{4}{|c|}{ Percent of Total Tax } \\
\hline & $B$ & C & $D$ & $E F G$ & $B$ & C & $D$ & $E F G$ & $B$ & C & $D$ & $E F G$ \\
\hline asl 1977 & & & & +3 & & & & +3 & & & & +3 \\
\hline psl 1977 & & & & +3 & & & & +3 & & & & +0 \\
\hline 1959 & +0 & +3 & +3 & +3 & +0 & +3 & +2 & +1 & +0 & +3 & +2 & +0 \\
\hline $\begin{array}{ll}\text { s } 1959 \\
\end{array}$ & & & & +3 & & & & +3 & & & & +3 \\
\hline 1947 & & & & +3 & & & & +3 & & & & +2 \\
\hline
\end{tabular}

Perhaps surprisingly, property taxes (rvTXPROP) are generally found to have a positive impact on state economic growth, a result that may be due to the improved local infrastructure that can be financed with higher property taxes.

\begin{tabular}{|c|c|c|c|c|c|c|c|c|c|c|c|c|}
\hline \multicolumn{10}{|c|}{ Variable: rvTXPROP } \\
\hline \multirow{2}{*}{ Year: $\mathrm{t}_{0}$} & $B$ & $C$ & $D$ & $E F G$ & $B$ & $C$ & $D$ & $E F G$ & $B$ & $C$ & $D$ & $E F G$ \\
\hline asl 1977 & & & & +3 & & & & +3 & & & & +3 \\
\hline ps1 1977 & & & & +3 & & & & +3 & & & & +3 \\
\hline 1959 & +3 & +3 & +2 & +3 & +3 & +2 & +2 & +3 & +3 & +0 & +0 & +3 \\
\hline s 1959 & & & & +0 & & & & -0 & & & & -0 \\
\hline 1947 & & & & -0 & & & & -1 & & & & -1 \\
\hline
\end{tabular}


The coefficient on total transfers from the federal government (rvTRFtot) is always positive, and generally significantly so.

\begin{tabular}{|c|c|c|c|c|c|c|c|c|c|c|c|c|c|}
\hline \multicolumn{10}{|c|}{ Variable: rvTRFtot } \\
\hline \multirow{2}{*}{ Year: $\mathrm{t}_{0}$} & $B$ & $C$ & $D$ & $E F G$ & $B$ & $C$ & $D$ & $E F G$ & $B$ & $C$ & $D$ & $E F G$ \\
\hline asl 1977 & & & & +3 & & & & +3 & & & & +3 \\
\hline ps1 1977 & & & & +3 & & & & +3 & & & & +3 \\
\hline 1959 & +2 & +3 & +3 & +3 & +0 & +2 & +1 & +3 & +1 & +3 & +2 & +0 \\
\hline s 1959 & & & & +3 & & & & +3 & & & & +3 \\
\hline 1947 & & & & +3 & & & & +2 & & & & +3 \\
\hline
\end{tabular}

Similarly, federal transfers for education (rvTRFedu) are significantly and positively correlated with income growth in all instances. The magnitude of coefficient indicates that each additional one dollar in per capita transfers is associated with an increase in per capita income growth rates by one-hundredth of a percentage point.

\begin{tabular}{|r|c|c|c|c|c|c|c|c|c|c|c|c|c|}
\hline \multicolumn{10}{|c|}{ Variable: rvTRFedu } \\
\hline \multirow{2}{*}{ Year: $\mathrm{t}_{0}$} & $B$ & $C$ & $D$ & $E F G$ & $B$ & $C$ & $D$ & $E F G$ & $B$ & $C$ & $D$ & $E F G$ \\
\hline asl 1977 & & & & +3 & & & & +3 & & & & +3 \\
\hline ps1 1977 & & & & +3 & & & & +3 & & & & +3 \\
\hline 1959 & +3 & +3 & +3 & +3 & +3 & +3 & +3 & +3 & +3 & +3 & +3 & +3 \\
\hline s 1959 & & & & +3 & & & & +3 & & & & +3 \\
\hline 1947 & & & & +3 & & & & +3 & & & & +3 \\
\hline
\end{tabular}

In contrast, federal transfers for highways (rvTRFhwy) are not consistently related to economic growth. Depending on the specification, the estimated coefficient is sometimes positive and significant, sometimes negative and significant, and sometimes insignificant. The negative relationship between highway transfers and growth is most pronounced after 1977, perhaps due to the need for state matching funds. Also, there are likely to be long lags associated with any benefits from highway construction.

\begin{tabular}{|l|c|c|c|}
\hline \multicolumn{4}{|c|}{ Variable: rvTRFhwy } \\
\hline & Per Capita & Percent of Income & Percent of Total Tax \\
\hline
\end{tabular}




\begin{tabular}{|c|c|c|c|c|c|c|c|c|c|c|c|c|}
\hline Year: $\mathrm{t}_{0}$ & $B$ & $C$ & $D$ & $E F G$ & $B$ & $C$ & $D$ & $E F G$ & $B$ & $C$ & $D$ & $E F G$ \\
\hline asl 1977 & & & & -3 & & & & -3 & & & & -3 \\
\hline psl 1977 & & & & -3 & & & & -3 & & & & -2 \\
\hline r 1959 & -0 & +0 & +0 & +1 & -0 & +0 & +0 & +0 & -0 & +0 & +0 & +0 \\
\hline s 1959 & & & & +1 & & & & +0 & & & & +0 \\
\hline & & & & & & & & & & \\
\hline
\end{tabular}

On the expenditure side, education expenditures (spEDUtot) are measured by spending on primary and secondary education. This variable is always negatively and significantly correlated with income growth. It is possible that greater expenditures on education reflect a higher proportion of the population under the age of 18 , and this larger population group may not contribute in a positive way to economic growth.

\begin{tabular}{|c|c|c|c|c|c|c|c|c|c|c|c|c|}
\hline \multicolumn{13}{|c|}{ Variable: spEDUtot } \\
\hline \multirow[b]{2}{*}{ Year: $t_{0}$} & \multicolumn{4}{|c|}{ Per Capita } & \multicolumn{4}{|c|}{ Percent of Income } & \multicolumn{4}{|c|}{ Percent of Total Tax } \\
\hline & $B$ & C & $D$ & $E F G$ & $B$ & $C$ & $D$ & $E F G$ & $B$ & $C$ & $D$ & $E F G$ \\
\hline asl 1977 & & & & -3 & & & & -3 & & & & -3 \\
\hline psl 1977 & & & & -3 & & & & -3 & & & & -3 \\
\hline 1959 & -3 & -3 & -3 & -3 & -3 & -3 & -3 & -3 & -3 & -3 & -3 & -3 \\
\hline s 1959 & & & & -3 & & & & -3 & & & & -3 \\
\hline 1947 & & & & -3 & & & & -3 & & & & -3 \\
\hline
\end{tabular}

Similarly, the estimated coefficient for expenditures on highways (including capital construction) always has a negative correlation with per capita income growth, and the coefficient is typically (though not always) significant. This result suggests that highway infrastructure does not contribute positively to sustained economic growth

\begin{tabular}{|c|c|c|c|c|c|c|c|c|c|c|c|c|}
\hline \multicolumn{13}{|c|}{ Variable: spHWYtot } \\
\hline \multirow[b]{2}{*}{ Year: $t_{0}$} & \multicolumn{4}{|c|}{ Per Capita } & \multicolumn{4}{|c|}{ Percent of Income } & \multicolumn{4}{|c|}{ Percent of Total Tax } \\
\hline & $B$ & C & $D$ & $E F G$ & $B$ & $C$ & $D$ & $E F G$ & $B$ & $C$ & $D$ & $E F G$ \\
\hline asl 1977 & & & & -3 & & & & -3 & & & & -3 \\
\hline psl 1977 & & & & -3 & & & & -3 & & & & -3 \\
\hline 1959 & -1 & -3 & -3 & -3 & -0 & -1 & -2 & -3 & -0 & -2 & -3 & -3 \\
\hline s 1959 & & & & -3 & & & & -3 & & & & -3 \\
\hline 1947 & & & & -3 & & & & -3 & & & & -3 \\
\hline
\end{tabular}


Welfare expenditures (spWELtot) include intergovernmental expenditures for locally administered welfare programs as well as expenditures to offset federal payments for supplemental programs; cash assistance is included, but health and hospital services are not. This variable is always negatively correlated with growth, although its coefficient is not always significant at conventional levels.

\begin{tabular}{|c|c|c|c|c|c|c|c|c|c|c|c|c|}
\hline \multicolumn{10}{|c|}{ Variable: spWELtot } \\
\hline \multirow{2}{*}{ Year: $\mathrm{t}_{0}$} & Per Capita & \multicolumn{3}{|c|}{ Percent of Income } & \multicolumn{3}{|c|}{ Percent of Total Tax } \\
\hline & $B$ & $C$ & $D$ & $E F G$ & $B$ & $C$ & $D$ & $E F G$ & $B$ & $C$ & $D$ & $E F G$ \\
\hline asl 1977 & & & & -3 & & & & -3 & & & & -3 \\
\hline ps1 1977 & & & & -3 & & & & -3 & & & & -3 \\
\hline 1959 & -1 & -3 & -3 & -3 & -0 & -1 & -2 & -3 & -0 & -2 & -3 & -3 \\
\hline s 1959 & & & & -3 & & & & -3 & & & & -3 \\
\hline 1947 & & & & -3 & & & & -3 & & & & -3 \\
\hline
\end{tabular}

Finally, spCAPhwy denotes direct capital outlays for the construction of roads and for the purchase of equipment, land, and other structures necessary for their use; it includes amounts for additions, for replacements, and for major alterations, but it excludes expenditures for repairs. One would expect a positive correlation between spCAPhwy and growth; however, the correlation is always negative and is often statistically significant.

\begin{tabular}{|r|c|c|c|c|c|c|c|c|c|c|c|c|}
\hline \multicolumn{10}{|c|}{ Variable: spCAPhwy } \\
\hline \multirow{2}{*}{ Year: $\mathrm{t}_{0}$} & $B$ & $C$ & $D$ & $E F G$ & $B$ & $C$ & $D$ & $E F G$ & $B$ & $C$ & $D$ & $E F G$ \\
\hline asl 1977 & & & & -0 & & & & -1 & & & & -1 \\
\hline ps1 1977 & & & & -0 & & & & -0 & & & & -0 \\
\hline 1959 & -3 & -1 & -0 & -0 & -0 & -2 & -0 & -0 & -0 & -2 & -0 & -0 \\
\hline s 1959 & & & & -3 & & & & -3 & & & & -3 \\
\hline 1947 & & & & -3 & & & & -3 & & & & -3 \\
\hline
\end{tabular}

Perhaps the most surprising of these fiscal results is the somewhat inconsistent impact of taxation on economic growth, as measured by total taxes, rvTXTOTAL. Results for the components of taxation are slightly more consistent, but these results often indicate a surprising 
positive (though often statistically insignificant) impact of taxes on growth. Also, transfers (in total and for education) typically have a positive and significant impact on growth, while transfers for highways generate mixed results. Indeed, the expenditure results are considerably more consistent than the tax results. In almost all cases, expenditures are negatively and significantly correlated with growth in per capita income, even spending that augments state infrastructure.

\subsection{Socio-economic, Demographic, Geographic, and Political Variables}

We have also included many other variables in various specifications. We do not discuss all of these results in detail, but it is useful to highlight some of the more provocative findings.

One political variable is a dummy variable that equals 1 if the governor of the state (in the previous year) is Republican and 0 otherwise (dmPOLgov). It is widely believed that Republicans are more sympathetic to, and more encouraging of, policies that generate economic growth. However, the estimated coefficient on dmPOLgov is always negative and often significantly so.

Similarly, we include a dummy variable equal to 1 if the state has a TEL in place (on either the tax or the expenditure side) and 0 otherwise (dmTXREF). It might be expected that such limitations increase growth by placing limits on the size and the reach of government; in contrast, a TEL might lead to reductions in government infrastructure and service spending, thereby reducing growth. In fact, we find that the coefficient on dmTXREF is always negative, though not always statistically significant. Regressions $F$ and $G$, which cover the period from 1977 to 1996 and which exclude the five high volatility states, indicate that passage of a TEL reduces per capita income growth by about three tenths of a percentage point.

\begin{tabular}{|l|c|c|c|}
\hline \multicolumn{4}{|c|}{ Variable: dmTAXref } \\
\hline & Per Capita & Percent of Income & Percent of Total Tax \\
\hline
\end{tabular}




\begin{tabular}{|c|c|c|c|c|c|c|c|c|c|c|c|c|}
\hline Year: $\mathrm{t}_{0}$ & $B$ & $C$ & $D$ & $E F G$ & $B$ & $C$ & $D$ & $E F G$ & $B$ & $C$ & $D$ & $E F G$ \\
\hline asl 1977 & & & & -3 & & & & -3 & & & & -3 \\
\hline ps1 1977 & & & & -3 & & & & -3 & & & & -3 \\
\hline 1959 & na & -1 & -1 & -3 & na & 0 & 0 & -3 & na & 0 & -1 & -3 \\
\hline s 1959 & & & & 0 & & & & -1 & & & & -1 \\
\hline & & & & 0 & & & & 0 & & & & 0 \\
\hline
\end{tabular}

Another political variable measures the frequency of party change (gePOLCgov). One can argue that a state that changes its governing party more frequently is somewhat unstable, which would inhibit growth. One can also argue that a higher value of gePOLCgov indicates a state with a greater willingness to undertake risks or a state with a balanced political orientation, both of which might be reflected in higher growth (Crain 2003). The sign of gePOLCgov is always positive and, at least since 1977, always significant.

We include various geographic variables, reflecting the size of the state's land area (geSIZ), the ratio of federal land to total land area (geSIZPf), and adjacency to the east coast (geREGatl) or the west coast (geREGpac). The coefficient on land area is seldom significant, and the coefficient on geSIZPf is generally negative and significant, indicating that federal occupation of state lands discourages economic growth. As for the adjacency variables, being on the Atlantic Ocean or the Gulf of Mexico tends to have a positive impact on growth, while being in a state that adjoins the Pacific Ocean has a consistent negative impact.

Demographic variables — the state's population in millions (dmPOP) or the ratio of state population to state land area $(\mathrm{dmDEN})$ - both have erratic and inconsistent impacts on growth. Several other variables that measure the coefficient of variation of wages in six employment sectors (dmWAGEcv) and the coefficient of variation of payrolls in these same sectors (dmPRNFPcv) also have inconsistent, though largely negative, effects on growth. Because larger values for these variables indicate greater disparity in either the level of wages 
(dmWAGEcv) or the level of employment (dmPRNFPcv) in these sectors, the negative coefficients on these variables suggest that the concentration of a state's employment base in fewer sectors has a positive effect on growth.

Overall, these different results tend to be somewhat more robust than those for the fiscal variables (especially the tax variables).

\section{$\underline{\text { 5. Conclusions }}$}

This paper reports the results of an empirical analysis of economic growth in the United States for the years 1947 through 1997, presenting empirical results against which theoretical models of economic growth can be compared. The analysis uses annual data to examine the effects of government policy variables at the state and local levels, as well as the effects of a wide range of other socio-economic, demographic, geographic, and political variables.

The empirical literature on economic growth includes hundreds of articles examining the growth effects of a multitude of variables. Our paper differs from these studies in several important ways: it examines annual data over a longer period than most other studies, it includes a much more comprehensive collection of explanatory variables, and it addresses the measurement errors inherent in per capita income data.

Several main conclusions emerge.

First, our estimation results indicate that a state's fiscal policies have a measurable relationship with per capita income growth, although not always in the expected direction and seldom in a way that is robust to alternative specifications. Tax impacts on state economic growth are quite variable; expenditure impacts are more consistent across different specifications. The statistically significant correlation between state (and state plus local) total 
tax revenues and economic growth is very sensitive to the regressor set and the time period examined. Often, there are highly significant correlations measured between these variables and per capita income growth, but further work needs to be done before it can be determined what these results mean.

Second, there is strong evidence that a state's political orientation, as indicated by whether the governor is Republican or Democrat, whether the state has enacted tax and expenditure limitation legislation, and whether the state frequently elects a governor of the same

party as the incumbent, have consistent, measurable, and significant effects on economic growth. Perhaps surprisingly, having a Republican governor is associated with lower rates of growth.

Third, the methods commonly employed for growth regression analyses could be inadequate and could adversely affect the results because most previously reported results have not taken measurement errors into account. Again, we do not discuss these results in detail here, but we have some evidence that it is very likely that measurement errors have had a significant impact on previously reported growth regression results, especially with regards to convergence. Indeed, although ordinary linear least squares estimates suggest that there is conditional convergence in per capita income across the 48 contiguous states, our ODR estimates indicate strong evidence of divergence.

\section{References}

Akai, Nobuo and Masayo Sakata. 2002. Fiscal Decentralization Contributes to Economic Growth: Evidence from State-level Cross-section Data for the United States. Journal of Urban Economics 52 (1): 93-108.

Barro, Robert J. and Xavier Sala-i-Martin. 1991. Convergence across States and Regions. Brookings Papers on Economic Activity 1 (1): 107-182. 
Barro, Robert J. and Xavier and Sala-i-Martin. 1992. Convergence. The Journal of Political Economy 100 (2): 223-251.

Barro, Robert J. and Xavier Sala-i-Martin. 1992. Public Finance in Models of Economic Growth. Review of Economic Studies 59 (4): 645-661.

Berry, Dan L. and David L. Kaserman. 1987. A Diffusion Model of Long-run State Economic Development. Atlantic Economic Journa/ 21 (4): 39-54.

Berry, William D., Richard C. Fording, and Russell L. Hanson. 2000. An annual cost of living index for the American states, 1960-1995. The Journal of Politics 62 (2): 550-567.

Boggs, Paul T., Richard H. Byrd, and Robert B. Schnabel. 1987. A Stable and Efficient Algorithm for Nonlinear Orthogonal Distance Regression. Society for Industrial and Applied Mathematics (SIAM) Journal of Scientific and Statistical Computing 8 (6): 1052-1078.

Boggs, Paul T., Janet Rogers Donaldson, Robert B. Schnabel, and Clifford H. Spiegelman. 1988. A Computational Examination of Orthogonal Distance Regression. Journal of Econometrics 38 (1/2): 169-201.

Canto, Victor and Robert I. Webb. 1987. The Effect of State Fiscal Policy on State Relative Economic Performance. Southern Economic Journal 54 (1): 186-202.

Caselli, Francesco and Wilbur John Coleman II. 2001. The U.S. Structural Transformation and Regional Convergence: A Reinterpretation. The Journal of Political Economy 109 (3): 584-616.

Coughlin, Cletus C. and Thomas B. Mandelbaum. 1989. Have Federal Spending and Taxation Contributed to the Divergence of State Per Capita Incomes in the 1980s? Federal Reserve Bank of St. Louis Review 71 (4): 29-42.

Crain, W. Mark and Katherine J. Lee. 1999. Economic Growth Regressions for the American States: A Sensitivity Analysis. Economic Inquiry 37 (2): 242-257.

Crain, W. Mark. 2003. Volatile States: Institutions, Policy, and the Performance of American State Economies. Ann Arbor, MI: The University of Michigan Press.

De Long, J. Bradford. 1988. Productivity Growth, Convergence, and Welfare: Comment. The American Economic Review 78 (5): 1138-1154.

Garofalo, Gasper A. and Steven Yamarik. 2002. Regional Convergence: Evidence from a New State-by-state Capital Stock Series. The Review of Economics and Statistics 84 (2): 316-323.

Holcombe, Randall G. and Donald J. Lacombe. 2004. The Effect of State Income Taxation on Per Capita Income Growth. Public Finance Review 32 (3): 292-312. 
Leamer, Edward E. 1983. Let's Take the Con Out of Econometrics. The American Economic Review 73 (1): 31-43.

Leamer, Edward E. 1985. Sensitivity Analysis Would Help. The American Economic Review 75 (3): 308-313.

Levine, Ross and David Renelt. 1992. A Sensitivity Analysis of Cross-country Growth Regressions. The American Economic Review 82 (4): 942-963.

Mofidi, Alaeddin and Joe A. Stone. 1990. Do State and Local Taxes Affect Economic Growth? The Review of Economics and Statistics 72 (4): 686-691.

Mullen, John K. and Martin Williams. 1994. Marginal Tax Rates and State Economic Growth. Regional Science and Urban Economics 24 (6): 687-705.

Persson, Torsten and Guido Tabellini. 1992. Growth, Distribution, and Politics. European Economic Review 36 (2-3): 593-602.

Phillips, Joseph M. and Ernest P. Goss. 1995. The Effect of State and Local Taxes on Economic Development: A Meta-analysis. Southern Economic Journal 62 (2): 320-333.

Reed, W. Robert. 2008a. The Robust Relationship between Taxes and U. S. State Income Growth. National Tax Journal 61 (1): 57-80.

Reed, W. Robert. 2008b. The Determinants of U.S. State Economic Growth: A Less Extreme Bounds Analysis. Economic Inquiry 47 (4): 685-700.

Romer, Paul M. 1987. Growth Based on Increasing Returns due to Specialization. The American Economic Review 77 (2): 56-62.

Romer, Paul M. 1990. Endogenous Technological Change. The Journal of Political Economy 98 (5, Part 2): S71-S102.

Sala-i-Martin, Xavier. 1997. I Just Ran Two Million Regressions. The American Economic Review, Papers and Proceedings of the American Economic Association 87 (2): 178-183.

Sala-i-Martin, Xavier, Gernot Doppelhofer, and Ronald I. Miller. 2004. Determinants of Longterm Growth: A Bayesian Averaging of Classical Estimates (BACE) Approach. The American Economic Review 94 (4): 813-835.

Solow, Robert M. 1956. A Contribution to the Theory of Economic Growth. The Quarterly Journal of Economics 70 (1): 65-94.

Swan, Trevor W. 1956. Economic Growth and Capital Accumulation. Economic Record 32: 334-361. 
Tomljanovich, Marc. 2004. The Role of State Fiscal Policy in State Economic Growth. Contemporary Economic Policy 22 (3): 318-330.

Weil, David N. 2005. Economic Growth. Boston, MA: Pearson Education, Inc. and AddisonWesley.

\section{Author Biographies}

James Alm is a professor of economics at Tulane University. Much of his research has examined the responses of individuals and firms to taxation, in such areas as tax compliance and tax evasion, the income tax treatment of the family, tax reform, social security, housing, and indexation. He has also worked extensively on fiscal reform projects overseas.

Janet Rogers received her Ph.D. in economics from the University of Colorado at Boulder, and has worked extensively on state and local fiscal issues. She currently is the Chief State Economist for the Department of Administration, Division of Budget and Planning, for the State of Nevada. Previously, she was the Senior Economist for the State of Colorado Governor's Office of State Planning and Budgeting. 
Table 1: State Per Capita Income Growth Rates

\begin{tabular}{|c|c|c|c|c|c|c|}
\hline Variable & & Minimum & Medium & Maximum & Mean & $\begin{array}{l}\text { Standard } \\
\text { Deviation }\end{array}$ \\
\hline \multirow[t]{55}{*}{ "GROWTH RATE } & 1947 to 1997 & -26.881343 & 2.599185 & 37.466502 & 2.463311 & (3.566412 \\
\hline & 1959 to 1997 & -11.979529 & 2.636467 & 37.466502 & 2.529837 & 2.928958 \\
\hline & 1977 to 1997 & -11.979529 & 2.342378 & 18.533654 & 2.221870 & 2.470992 \\
\hline & 1947 & -7.188256 & 2.688347 & 27.763463 & 3.380174 & 6.392585 \\
\hline & 1959 & -2.399308 & 1.337050 & 17.540014 & 1.412017 & 2.892205 \\
\hline & 1977 & 2.035510 & 4.751758 & 18.533654 & 5.280604 & 2.562704 \\
\hline & 1997 & -2.094665 & 2.794675 & 4.523854 & 2.759872 & 1.034305 \\
\hline & $\mathrm{AL}$ & -5.449525 & 2.757499 & 10.047148 & 3.004919 & 2.653822 \\
\hline & $A Z$ & -5.314906 & 2.461079 & 11.169953 & 2.346481 & 3.042259 \\
\hline & AR & -8.250670 & 3.003985 & 13.210948 & 3.085245 & 3.615919 \\
\hline & $\mathrm{CA}$ & -2.719498 & 2.190122 & 8.734397 & 1.965693 & 2.381787 \\
\hline & $\mathrm{CO}$ & -4.607509 & 2.588700 & 10.584516 & 2.473059 & 2.479050 \\
\hline & CT & -5.192651 & 3.113621 & 12.823114 & 2.616590 & 3.251940 \\
\hline & DE & -7.124412 & 2.195789 & 14.270855 & 2.188016 & 3.414032 \\
\hline & $\mathrm{FL}$ & -3.742361 & 3.039199 & 9.763492 & 2.619060 & 2.772511 \\
\hline & GA & -3.106167 & 3.019119 & 8.839196 & 3.103741 & 2.709899 \\
\hline & ID & -6.785022 & 2.230977 & 11.222756 & 2.047681 & 3.439490 \\
\hline & IL & -7.220754 & 2.590271 & 8.517273 & 2.164266 & 2.737236 \\
\hline & IN & -8.058500 & 2.496404 & 10.963497 & 2.263290 & 3.652122 \\
\hline & IA & -17.425284 & 2.879678 & 27.763463 & 2.534621 & 6.242572 \\
\hline & KS & -5.785119 & 1.958987 & 11.795970 & 2.323780 & 3.257377 \\
\hline & KY & -5.841354 & 3.186884 & 9.025797 & 2.851088 & 2.821149 \\
\hline & LA & -2.748423 & 3.172533 & 9.069085 & 2.782600 & 2.351436 \\
\hline & $\mathrm{ME}$ & -4.188888 & 2.615366 & 7.570101 & 2.358116 & 2.724728 \\
\hline & MD & -4.977451 & 2.975081 & 8.812488 & 2.608829 & 2.389123 \\
\hline & MA & -2.141386 & 2.639059 & 10.893857 & 2.660012 & 2.653370 \\
\hline & MI & -6.957617 & 2.474794 & 11.552469 & 2.200374 & 3.878417 \\
\hline & MN & -8.526884 & 2.608256 & 10.877609 & 2.573086 & 3.145711 \\
\hline & MS & -12.277717 & 3.041126 & 13.491000 & 3.151690 & 4.153382 \\
\hline & MO & -3.532584 & 2.639179 & 7.185746 & 2.413513 & 2.341626 \\
\hline & MT & -14.136631 & 1.051058 & 16.304480 & 1.726461 & 4.744971 \\
\hline & NE & -13.609717 & 1.916035 & 15.952952 & 2.427993 & 5.118237 \\
\hline & NV & -6.058414 & 2.187897 & 9.921601 & 1.925878 & 3.379783 \\
\hline & $\mathrm{NH}$ & -2.985046 & 3.202911 & 9.119015 & 2.763886 & 2.660554 \\
\hline & NJ & -3.454446 & 2.820757 & 10.006480 & 2.543315 & 2.504472 \\
\hline & NM & -2.344977 & 2.292986 & 6.896486 & 2.366553 & 1.698676 \\
\hline & NY & -3.154640 & 2.156333 & 8.891542 & 2.220444 & 2.295454 \\
\hline & NC & -4.031960 & 3.202856 & 10.020423 & 3.011300 & 2.758439 \\
\hline & ND & -18.446142 & 0.274876 & 37.466502 & 2.147741 & 10.457444 \\
\hline & $\mathrm{OH}$ & -5.514968 & 2.415200 & 9.547198 & 2.201988 & 3.106119 \\
\hline & OK & -4.775598 & 2.425839 & 6.657016 & 2.444566 & 2.522105 \\
\hline & OR & -4.185013 & 2.388269 & 9.642536 & 2.024612 & 2.609964 \\
\hline & PA & -4.562608 & 2.986885 & 9.507484 & 2.359050 & 2.391755 \\
\hline & RI & -7.188256 & 2.846378 & 11.645216 & 2.242600 & 3.076794 \\
\hline & SC & -6.559704 & 2.923692 & 12.802803 & 3.053797 & 3.375291 \\
\hline & SD & -26.881343 & 2.507430 & 19.887830 & 2.411537 & 8.079090 \\
\hline & $\mathrm{TN}$ & -2.489182 & 2.840871 & 8.866908 & 2.982792 & 2.497893 \\
\hline & $\mathrm{TX}$ & -2.192101 & 2.556739 & 7.301671 & 2.538288 & 2.181111 \\
\hline & UT & -2.770354 & 2.119372 & 7.501084 & 2.165610 & 2.080932 \\
\hline & VT & -5.612176 & 2.645886 & 9.100968 & 2.535519 & 2.813045 \\
\hline & VA & -1.978435 & 3.095995 & 10.022425 & 3.021686 & 2.503227 \\
\hline & WA & -2.749638 & 2.223326 & 7.612945 & 2.219363 & 2.377244 \\
\hline & WV & -7.859453 & 2.589515 & 8.211955 & 2.293188 & 2.819456 \\
\hline & WI & -4.567007 & 2.494046 & 10.469997 & 2.351700 & 2.780058 \\
\hline & WY & -5.819025 & 2.033767 & 8.776452 & 1.923314 & 3.262017 \\
\hline
\end{tabular}

Values are the year-to-year percent change in real per capita income, computed as $\mathrm{g}_{\mathrm{s}, \mathrm{t}}=\left(\mathrm{y}_{\mathrm{s}, \mathrm{t}-1}-\mathrm{y}_{\mathrm{s}, \mathrm{t}}\right) / \mathrm{y}_{\mathrm{s}, \mathrm{t}}$. 
Table 2: State Revenue Variables

\begin{tabular}{lllll}
\hline Variable Name & Class & Subclass & Qualifier & Units \\
\hline \hline rvTXTOTAL & Tax & none & total taxes from all sources & real U.S.\$ \\
rvTXCON & Tax & consumption & total (sales + income) & real U.S.\$ \\
rvTXINCtot & Tax & consumption & income: total (individual + corporate) real U.S.\$ \\
rvTXINCcor & Tax & consumption & income: corporate & real U.S.\$ \\
rvTXINCind & Tax & consumption & income: individual & real U.S.\$ \\
rvTXSALtot & Tax & consumption & sales: total (general + selective) & real U.S.\$ \\
rvTXSALgen & Tax & consumption & sales: general & real U.S.\$ \\
rvTXSALsel & Tax & consumption & sales: selective & real U.S.\$ \\
rvTXPROP & Tax & wealth & property & real U.S.\$ \\
rvTXSEV & Tax & other & severance & real U.S.\$ \\
rvTXNEC & Tax & other & not elsewhere classified & real U.S.\$ \\
rvTRFtot & Transfers & federal & total transfer & real U.S.\$ \\
rvTRFedu & Transfers & federal & transfers for education & real U.S.\$ \\
rvTRFhwy & Transfers & federal & transfers for highways & real U.S.\$ \\
rvTRFnec & Transfers & federal & not elsewhere classified & real U.S.\$
\end{tabular}

Table 3: State Expenditure Variables

\begin{tabular}{lllll}
\hline Variable Name & Class & Subclass & Qualifier & Units \\
\hline \hline spEDUtot & spending & None & education: total (general + higher + capital outlays) \\
spEDUgen & spending & None & education: general primary and secondary, including capital construction & real U.S.\$ \\
spEDUhi & spending & None & education: higher, including capital construction & real U.S.\$ \\
spHWYtot & spending & None & highways: total & real U.S.\$ \\
spWELtot & spending & None & welfare: total & real U.S.\$ \\
spHHtot & spending & None & health and hospitals: total & real U.S.\$ \\
spPPtot & spending & None & police protection & real U.S.\$ \\
spNEC & spending & None & not elsewhere classified & real U.S.\$ \\
spCAPtot & spending & Capital & total & real U.S.\$ \\
spCAPhwy & spending & Capital & highways & real U.S.\$ \\
spCAPedu & spending & Capital & education & real U.S.\$ \\
spCAPnec & spending & Capital & not elsewhere classified &
\end{tabular}

Table 4: State Demographic Variables

\begin{tabular}{|c|c|c|c|c|}
\hline $\begin{array}{l}\text { Variable } \\
\text { Name }\end{array}$ & Class & Subc & Qualifier & Units \\
\hline$\overline{\mathrm{dmPOP}}$ & population & none & total & thousands of persons \\
\hline dmDEN & population & none & population density & population per land area \\
\hline dmDENsq & population & none & squared population density & $\begin{array}{l}\text { squared population per } \\
\text { land area }\end{array}$ \\
\hline dmDENnf & population & none & population density on nonfederal land & population per land area \\
\hline dmDENnfsq & population & none & squared population density on nonfederal land & $\begin{array}{l}\text { squared population per } \\
\text { land area }\end{array}$ \\
\hline dmPOLgov & political orientation & none & Republican governor & dummy variable \\
\hline dmPOLup & political orientation & none & Republican majority in upper house & dummy variable \\
\hline dmPOLlow & political orientation & none & Republican majority in lower house & dummy variable \\
\hline dmPOLboth & political orientation & none & Republican majority in both houses & dummy variable \\
\hline dmPOLnone & political orientation & none & Republican majority in neither house & dummy variable \\
\hline dmPOLallR & political orientation & none & $\begin{array}{l}\text { Republican governor and Republican majority in both } \\
\text { houses }\end{array}$ & dummy variable \\
\hline dmPOLallD & political orientation & none & $\begin{array}{l}\text { not Republican governor and not Republican majority in } \\
\text { either house }\end{array}$ & dummy variable \\
\hline dmTXref & political orientation & none & tax and expenditure limit enacted & dummy variable \\
\hline dmTXsvl & political orientation & none & $\begin{array}{l}\text { percentage of total state plus local tax revenues collected } \\
\text { at the state level }\end{array}$ & Percent \\
\hline dmPRNFPcv & payroll distribution & none & coefficient of variation of private sector payrolls & percent of population \\
\hline $\begin{array}{l}\text { dmISNFPcV } \\
\text { dmWAGEcV }\end{array}$ & $\begin{array}{l}\text { income distribution } \\
\text { wage distribution }\end{array}$ & $\begin{array}{l}\text { none } \\
\text { none }\end{array}$ & $\begin{array}{l}\text { coefficient of variation of private sector incomes sources } \\
\text { coefficient of variation of private sector wages }\end{array}$ & $\begin{array}{l}\text { percent of population } \\
\text { percent of population }\end{array}$ \\
\hline
\end{tabular}




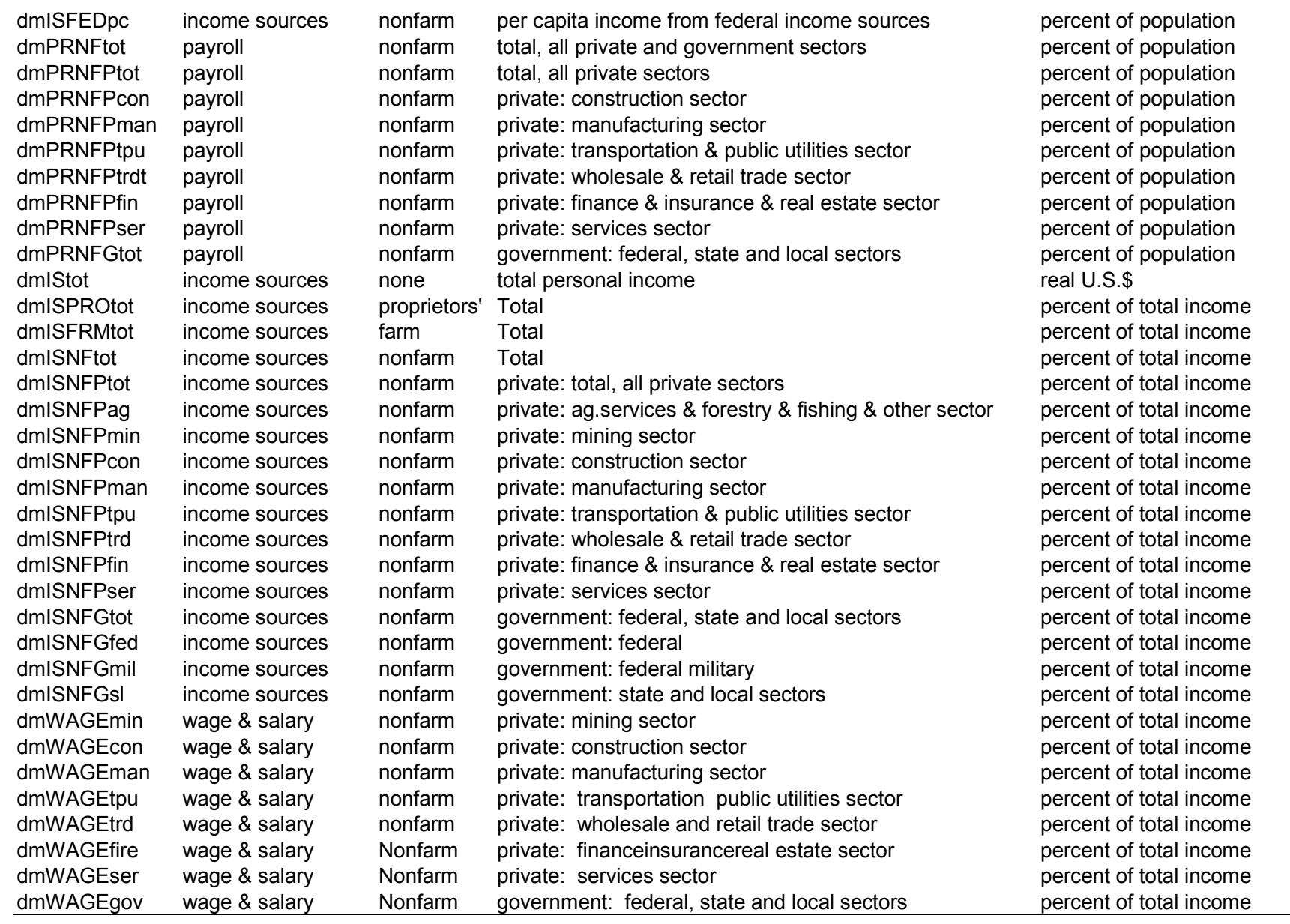

Table 5: State Geographic Variables

\begin{tabular}{|c|c|c|c|c|}
\hline Variable Name & Class & Subclass & Qualifier & Units \\
\hline geHEtotP & people & $\begin{array}{l}\text { socio- } \\
\text { economic }\end{array}$ & 1947 higher education enrollment: total first time students & percent of 1947 population \\
\hline geHEwmP & people & $\begin{array}{l}\text { socio- } \\
\text { economic }\end{array}$ & 1947 higher education enrollment: women first time students & percent of 1947 enrollment \\
\hline geSIZt & land & Area & total excluding water areas & hundreds of square miles \\
\hline geSIZPf & land & Area & federal surface area, 1982 & percent of total state area \\
\hline geSIZPw & land & Area & woodlands, 1982 & percent of total state area \\
\hline geSIZPr & land & Area & rangelands, 1982 & percent of total state area \\
\hline gePOLstate & political orientation & None & statehood granted prior to 1800 & dummy variable \\
\hline gePOLgov & political orientation & None & average of $d m P O L g o v s, t$ for all $t$ & percent \\
\hline gePOLup & political orientation & None & average of dmPOLup $\mathrm{s}_{\mathrm{s}, \mathrm{t}}$ for all $\mathrm{t}$ & percent \\
\hline gePOLlow & political orientation & None & average of dmPOLlow ${ }_{s, t}$ for all $t$ & percent \\
\hline gePOLboth & political orientation & None & average of dmPOLboth $\mathrm{s}_{\mathrm{s}, \mathrm{t}}$ for all $\mathrm{t}$ & percent \\
\hline gePOLnone & political orientation & None & average of dmPOLnone ${ }_{s, t}$ for all $t$ & percent \\
\hline gePOLallR & political orientation & None & average of $\mathrm{dmPOLall} \mathrm{R}_{\mathrm{s}, \mathrm{t}}$ for all $\mathrm{t}$ & percent \\
\hline gePOLallD & political orientation & None & average of dmPOLall $D_{s, t}$ for all $t$ & percent \\
\hline gePOLCgov & political orientation & None & standard deviation of dmPOLgov $v_{s, t}$ for all $t$ & percent \\
\hline gePOLCup & political orientation & None & standard deviation of dmPOLup $p_{s, t}$ for all $t$ & percent \\
\hline gePOLClow & political orientation & None & standard deviation of dmPOLlow ${ }_{s, t}$ for all $t$ & percent \\
\hline gePOLCboth & political orientation & None & standard deviation of dmPOLboth ${ }_{s, t}$ for all $t$ & percent \\
\hline gePOLCnone & political orientation & None & standard deviation of dmPOLnone $e_{s, t}$ for all $t$ & percent \\
\hline gePOLCallR & political orientation & None & standard deviation of $d m P O L a l l R_{s, t}$ for all $t$ & percent \\
\hline gePOLCallD & political orientation & None & standard deviation of dmPOLallD $\mathrm{D}_{\mathrm{s}, \mathrm{t}}$ for all $\mathrm{t}$ & percent \\
\hline geREG1 & land & Region & New England(CT, ME, MA, NH, RI, VT) & dummy variable \\
\hline
\end{tabular}




$\begin{array}{ll}\text { geREG2 } & \text { Land } \\ \text { geREG3 } & \text { Land } \\ \text { geREG4 } & \text { Land } \\ \text { geREG5 } & \text { Land } \\ \text { geREG6 } & \text { Land } \\ \text { geREG7 } & \text { Land } \\ \text { geREG8 } & \text { Land } \\ \text { geREG9 } & \text { Land } \\ \text { geREGatl } & \text { Land } \\ \text { geREGpac } & \text { Land } \\ \text { geREGcan } & \text { Land } \\ \text { geREGmex } & \text { Land } \\ \text { geREGcon } & \text { Land } \\ \text { geCRrt } & \text { Land } \\ \text { geCRhst } & \text { Land } \\ \text { geCRhc } & \text { Land } \\ \text { geCRmt } & \text { Land } \\ \text { geCRmed } & \text { Land } \\ \text { geCRsa } & \text { Land } \\ \text { geCRd } & \text { Land } \\ \text { geCRarc } & \text { Land } \\ \text { geCRalp } & \text { Land } \\ \text { geMNau } & \text { Land } \\ \text { geMNcoal } & \text { Land } \\ \text { geMNfe } & \text { Land } \\ \text { geMNgas } & \text { Land } \\ \text { geMNmo } & \text { Land } \\ \text { geMNoil } & \text { Land } \\ \text { geMNu } & \text { Land } \\ \text { geMNfuel } & \text { Land } \\ \text { geMN } & \text { Land } \\ \text { geAGwt } & \text { Land } \\ \text { geAGcn } & \text { Land } \\ \text { geAG } & \text { Land } \\ & \\ & \end{array}$

Region middle Atlantic (DE, MD, NJ, NY, PA)

dummy variable dummy variable dummy variable

Region west north central (IA, KS, MN, MO, NE, ND, SD)

Region south Atlantic (AL, AR, FL, GA, KY, LA, MS, NC, SC, TN, VA, WV)

Region east south central (AZ, NM, OK, TX)

Region

Region

mountain (CO, ID, MT, UT, WY)

Region

noncontiguous U.S. (AK, HI)

east coast

Region west coast

Region Canada border

Region Mexico border

Region constant

Climate rainy-tropical

Climate humid-subtropical

Climate humid-continental

Climate marine-temperate

Climate Mediterranean

Climate semi-arid

Climate desert

Climate arctic and sub-arctic

Climate alpine

Resources gold deposits

Resources coal deposits

Resources iron ore deposits

Resources natural gas deposits

Resources molybdenum deposits

Resources petroleum deposits

Resources uranium deposits

Resources coal, natural gas and/or petroleum deposits

Resources gold, coal, iron ore, natural gas, molybdenum, or petroleum deposits

agricultural wheat production

agricultural corn production

agricultural wheat and/or corn production

dummy variable

dummy variable

dummy variable

dummy variable

dummy variable

dummy variable

dummy variable

dummy variable

dummy variable

dummy variable

dummy variable

dummy variable

dummy variable

dummy variable

dummy variable

dummy variable

dummy variable

dummy variable

dummy variable

dummy variable

dummy variable

dummy variable

dummy variable

dummy variable

dummy variable

dummy variable

dummy variable

dummy variable

dummy variable

dummy variable

dummy variable

Table 6: Variables Associated with the U.S. as a Whole

\begin{tabular}{lllll}
\hline Variable Name & Class & Subclass & Qualifier & Units \\
\hline \hline usFUELpp & miscellaneous & None & average producer price for fuels & real u.s.\$ \\
usDEFcw & miscellaneous & None & chained weight deflator $(1996=1.0)$ & percent \\
usDEFfw & miscellaneous & None & fixed weight deflator $(1996=1.0)$ & percent \\
usPOP & miscellaneous & None & total population of 48 contiguous states (excluding DC) & thousands of persons \\
usINCtot & miscellaneous & None & total income of 48 contiguous states (excluding DC) & thousands of persons \\
usGRW & miscellaneous & None & U.S. growth rate & percent \\
usINF & miscellaneous & None & U.S. inflation rate & percent \\
\hline
\end{tabular}


Figure 1: Difference between Individual State and U.S. Average Growth Rates, 1947-1997

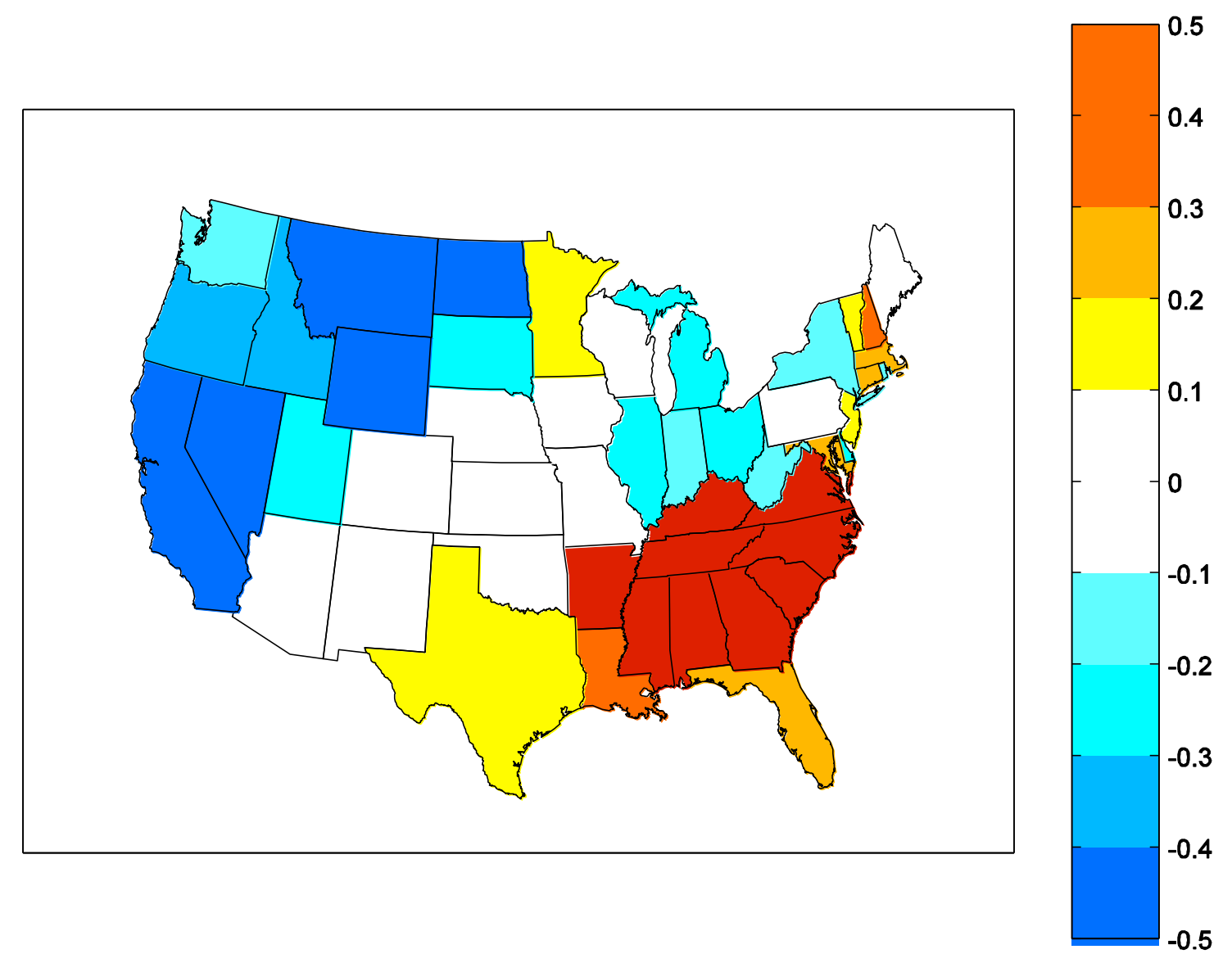




\section{Appendix Tables}

Table A1: Regression A $(1959-1997)^{\mathrm{a}}$

\begin{tabular}{|c|c|c|c|c|c|}
\hline Variable & Method & Estimate & $\begin{array}{l}\text { Standard } \\
\text { Deviation }\end{array}$ & $\begin{array}{c}t \text {-value } \\
H_{0}: \theta_{i}=0 \\
H_{0}: \theta_{i} \neq 0\end{array}$ & $\begin{array}{c}\text { One-Sided } \\
\text { Marginal } \\
\text { Significance } \\
\text { Level }\end{array}$ \\
\hline \multirow[t]{2}{*}{ usGRW } & odr & 0.9302812 & 0.0289600 & 32.12 & $0.00 \%$ *** \\
\hline & Ils & 0.8378600 & 0.0531617 & 15.76 & $0.00 \%^{* * *}$ \\
\hline \multirow[t]{2}{*}{ usINF } & odr & 0.0000929 & 0.0001454 & 0.64 & $26.14 \%$ \\
\hline & Ils & 0.0001690 & 0.0001344 & 1.26 & $10.44 \%$ \\
\hline \multirow[t]{2}{*}{ usFUELpp } & odr & -0.0019124 & 0.0003440 & -5.56 & $0.00 \%$ *** \\
\hline & Ils & -0.0019699 & 0.0003242 & -6.08 & $0.00 \%$ *** \\
\hline \multirow[t]{2}{*}{ geREGcon } & odr & 0.0160398 & 0.0020163 & 7.96 & $0.00 \%$ *** \\
\hline & Ils & 0.0203461 & 0.0019015 & 10.70 & $0.00 \%$ *** \\
\hline \multirow[t]{2}{*}{ gePOLstate } & odr & 0.0036382 & 0.0006269 & 5.80 & $0.00 \%$ *** \\
\hline & Ils & 0.0034087 & 0.0001286 & 26.51 & $0.00 \%$ *** \\
\hline \multirow[t]{2}{*}{$\overline{y_{0}}$} & odr & -0.0012481 & 0.0001683 & -7.42 & $0.00 \%^{* * *}$ \\
\hline & Ils & -0.0015189 & 0.0000344 & -44.21 & $0.00 \%$ *** \\
\hline \multirow{2}{*}{ Rho } & odr & 0.0099271 & 0.0015337 & 6.47 & $0.00 \%^{* * *}$ \\
\hline & Ils & 0.0046268 & 0.0004614 & 10.03 & $0.00 \%$ *** \\
\hline \multirow[t]{2}{*}{$\overline{\mathrm{R}^{2}}$} & $\overline{~ o d r}$ & 99.9 & & & \\
\hline & Ils & 96.7 & & & \\
\hline \multirow[t]{2}{*}{$\overline{\ell(\cdot)}$} & odr & -9781.8 & & & \\
\hline & Ils & -12325.3 & & & \\
\hline \multirow{3}{*}{$\overline{\sigma_{\varepsilon}}$} & odr & 163.1 & & & \\
\hline & nls & 1032.7 & & & \\
\hline & Ils & 0.05554 & & & \\
\hline \multirow{2}{*}{$\sigma_{\varepsilon}$} & odr & 165.2 & & & \\
\hline & Ils & $\mathrm{Na}$ & & & \\
\hline \multirow{2}{*}{$\begin{array}{l}\sigma_{\varepsilon} \\
y_{\mathrm{t} 0}\end{array}$} & odr & 39.2 & & & \\
\hline & Ils & $\mathrm{Na}$ & & & \\
\hline \multirow{2}{*}{$\begin{array}{c}\sigma_{\varepsilon} \\
\gamma\end{array}$} & odr & 0.00914 & & & \\
\hline & Ils & $\mathrm{Na}$ & & & \\
\hline
\end{tabular}

*** indicates $\mathrm{H}_{0}$ is rejected at $\alpha=5 \%$ significance level.

** $\quad$ indicates $\mathrm{H}_{0}$ is rejected at $\alpha=10 \%$ significance level.

* indicates $\mathrm{H}_{0}$ is rejected at $\alpha=20 \%$ significance level.

$\ell(\cdot)$ denotes the value of the likehood function. $\left[\sigma_{\varepsilon}, \sigma_{\varepsilon y}, \sigma_{\varepsilon y t 0}, \sigma_{\gamma}\right]$ denotes the standard deviations of the estimated residuals, the measurement error of income, the measurement error for initial income $\mathrm{y}_{0}$, and the model, respectively; the standard deviation $\sigma_{\varepsilon}$ is a weighted average of the measurement error standard deviations and the model standard deviation. 
Table A2: Regression B (per capita; $1959-1997)^{\mathrm{a}}$

\begin{tabular}{|c|c|c|c|c|c|}
\hline Variable & Method & Estimate & $\begin{array}{l}\text { Standard } \\
\text { Deviation }\end{array}$ & $\begin{array}{c}t \text {-value } \\
H_{0}: \theta_{i}=0 \\
H_{0}: \theta_{i} \neq 0 \\
\end{array}$ & $\begin{array}{c}\text { One-Sided } \\
\text { Marginal } \\
\text { Significance } \\
\text { Level } \\
\end{array}$ \\
\hline \multirow[t]{2}{*}{ usGRW } & odr & 0.9164151 & 0.0305155 & 30.03 & $0.00 \%$ *** \\
\hline & Ils & 0.8094562 & 0.0486160 & 16.65 & $0.00 \%$ *** \\
\hline \multirow{2}{*}{ usINF } & odr & -0.0005217 & 0.0001752 & -2.98 & $0.15 \%$ *** \\
\hline & Ils & 0.0000344 & 0.0001224 & 0.28 & $38.94 \%$ \\
\hline \multirow[t]{2}{*}{ usFUELpp } & odr & -0.0022860 & 0.0004129 & -5.54 & $0.00 \%$ *** \\
\hline & Ils & -0.0018108 & 0.0003250 & -5.57 & $0.00 \%$ *** \\
\hline \multirow[t]{2}{*}{ geREGcon } & odr & 0.0159364 & 0.0028225 & 5.65 & $0.00 \%$ *** \\
\hline & Ils & 0.0251525 & 0.0017342 & 14.50 & $0.00 \%$ *** \\
\hline \multirow[t]{2}{*}{ gePOLstate } & odr & 0.0026335 & 0.0007548 & 3.49 & $0.02 \%$ *** \\
\hline & Ils & 0.0024147 & 0.0001521 & 15.88 & $0.00 \%$ *** \\
\hline \multirow[t]{2}{*}{$\mathrm{y}_{0}$} & odr & -0.0005696 & 0.0002808 & -2.03 & $2.13 \%$ *** \\
\hline & Ils & -0.0019923 & 0.0000757 & -26.31 & $0.00 \%$ *** \\
\hline \multirow[t]{2}{*}{ rho } & odr & 0.0100623 & 0.0015213 & 6.61 & $0.00 \%$ *** \\
\hline & Ils & 0.0049265 & 0.0004665 & 10.56 & $0.00 \%$ *** \\
\hline \multirow[t]{2}{*}{ rvTXTOTAL } & odr & 0.0031377 & 0.0027695 & 1.13 & $12.87 \%$ \\
\hline & Ils & 0.0082254 & 0.0008457 & 9.73 & $0.00 \%$ *** \\
\hline \multirow{2}{*}{ rvTXINCcor } & odr & 0.0089821 & 0.0097420 & 0.92 & $17.83 \%$ \\
\hline & Ils & 0.0034075 & 0.0028961 & 1.18 & $11.98 \%$ \\
\hline \multirow[t]{2}{*}{ rvTXINCind } & odr & 0.0032783 & 0.0030738 & 1.07 & $14.32 \%$ \\
\hline & Ils & -0.0022551 & 0.0008762 & -2.57 & $0.51 \%$ *** \\
\hline \multirow{2}{*}{ rvTXSALgen } & odr & 0.0028672 & 0.0032352 & 0.89 & $18.78 \%$ \\
\hline & Ils & -0.0002181 & 0.0008425 & -0.26 & $39.79 \%$ \\
\hline \multirow[t]{2}{*}{ rvTXPROP } & odr & 0.0060951 & 0.0024430 & 2.49 & $0.63 \%^{* * *}$ \\
\hline & Ils & 0.0022668 & 0.0005968 & 3.80 & $0.01 \%$ *** \\
\hline \multirow[t]{2}{*}{ rvTRFtot } & odr & 0.0090632 & 0.0046069 & 1.97 & $2.47 \%$ *** \\
\hline & Ils & -0.0018527 & 0.0017677 & -1.05 & $14.74 \%$ \\
\hline \multirow[t]{2}{*}{ rvTRFedu } & odr & 0.1209462 & 0.0185788 & 6.51 & $0.00 \%$ *** \\
\hline & Ils & 0.0326072 & 0.0062439 & 5.22 & $0.00 \%$ *** \\
\hline \multirow[t]{2}{*}{ rvTRFhwy } & odr & -0.0036942 & 0.0127112 & -0.29 & $38.57 \%$ \\
\hline & Ils & -0.0250445 & 0.0039599 & -6.32 & $0.00 \%$ *** \\
\hline \multirow[t]{2}{*}{ spEDUtot } & odr & -0.0210545 & 0.0033184 & -6.34 & $0.00 \%$ *** \\
\hline & Ils & -0.0119434 & 0.0010889 & -10.97 & $0.00 \%$ *** \\
\hline \multirow[t]{2}{*}{ spHWYtot } & odr & -0.0017725 & 0.0098695 & -0.18 & $42.87 \%$ \\
\hline & Ils & -0.0061415 & 0.0024377 & -2.52 & $0.59 \%^{* * *}$ \\
\hline \multirow{2}{*}{ spWELtot } & odr & -0.0095676 & 0.0046721 & -2.05 & $2.04 \%$ *** \\
\hline & Ils & -0.0080643 & 0.0017390 & -4.64 & $0.00 \%$ *** \\
\hline \multirow[t]{2}{*}{ spCAPhwy } & odr & -0.0129220 & 0.0136243 & -0.95 & $17.15 \%$ \\
\hline & Ils & 0.0182959 & 0.0041463 & 4.41 & $0.00 \%$ *** \\
\hline \multirow{2}{*}{$\mathrm{R}^{2}$} & odr & 99.9 & & & \\
\hline & Ils & 97.5 & & & \\
\hline$\ell(\cdot)$ & odr & -9737.6 & & & \\
\hline & Ils & -12026.7 & & & \\
\hline$\sigma_{\varepsilon}$ & odr & 161.4 & & & \\
\hline & nls & 872.9 & & & \\
\hline & Ils & 0.04801 & & & \\
\hline$\sigma_{\varepsilon}$ & odr & 163.4 & & & \\
\hline $\mathrm{y}$ & Ils & $\mathrm{Na}$ & & & \\
\hline$\sigma_{\varepsilon}$ & odr & 40.7 & & & \\
\hline $\mathrm{y}_{\mathrm{t} 0}$ & Ils & $\mathrm{Na}$ & & & \\
\hline$\sigma_{\varepsilon}$ & odr & 0.00881 & & & \\
\hline$\gamma$ & Ils & $\mathrm{Na}$ & & & \\
\hline
\end{tabular}

*** indicates $\mathrm{H}_{0}$ is rejected at $\alpha=5 \%$ significance level.

** indicates $\mathrm{H}_{0}$ is rejected at $\alpha=10 \%$ significance level.

* indicates $\mathrm{H}_{0}$ is rejected at $\alpha=20 \%$ significance level.

a $\ell(\cdot)$ denotes the value of the likehood function. $\left[\sigma_{\varepsilon}, \sigma_{\varepsilon y}, \sigma_{\varepsilon y t 0}, \sigma_{\gamma}\right]$ denotes the standard deviations of the estimated residuals, the measurement error of income, the measurement error for initial income $\mathrm{y}_{0}$, and the model, respectively; the standard deviation $\sigma_{\varepsilon}$ is a weighted average of the measurement error standard deviations and the model standard deviation. 
Table A3: Regression C (per capita; $1959-1997)^{\mathrm{a}}$

\begin{tabular}{|c|c|c|c|c|c|}
\hline Variable & Method & Estimate & $\begin{array}{l}\text { Standard } \\
\text { Deviation }\end{array}$ & $\begin{array}{c}t \text {-value } \\
H_{0}: \theta_{i}=0 \\
H_{0}: \theta_{i} \neq 0\end{array}$ & $\begin{array}{c}\text { One-Sided } \\
\text { Marginal } \\
\text { Significance } \\
\text { Level }\end{array}$ \\
\hline \multirow[t]{2}{*}{ usGRW } & odr & 0.9103451 & 0.0315407 & 28.86 & $0.00 \%$ *** \\
\hline & Ils & 0.9114855 & 0.0458009 & 19.90 & $0.00 \%$ *** \\
\hline \multirow[t]{2}{*}{ usINF } & odr & -0.0008893 & 0.0002041 & -4.36 & $0.00 \%$ *** \\
\hline & Ils & -0.0001180 & 0.0001151 & -1.03 & $15.26 \%$ \\
\hline \multirow[t]{2}{*}{ usFUELpp } & odr & -0.0034089 & 0.0005795 & -5.88 & $0.00 \%^{* * *}$ \\
\hline & Ils & -0.0034584 & 0.0004359 & -7.93 & $0.00 \%$ *** \\
\hline \multirow[t]{2}{*}{ geREGcon } & odr & 0.0308275 & 0.0106647 & 2.89 & $0.19 \%$ *** \\
\hline & Ils & 0.0359358 & 0.0031414 & 11.44 & $0.00 \%$ *** \\
\hline \multirow[t]{2}{*}{ gePOLstate } & odr & 0.0031325 & 0.0011917 & 2.63 & $0.43 \%$ *** \\
\hline & Ils & 0.0018480 & 0.0002333 & 7.92 & $0.00 \%$ *** \\
\hline \multirow[t]{2}{*}{$\overline{y_{0}}$} & odr & 0.0016896 & 0.0005873 & 2.88 & $0.20 \%$ *** \\
\hline & Ils & -0.0008591 & 0.0001285 & -6.68 & $0.00 \%$ *** \\
\hline \multirow[t]{2}{*}{ Rho } & odr & 0.0099415 & 0.0015490 & 6.42 & $0.00 \%^{* * *}$ \\
\hline & Ils & 0.0080705 & 0.0005671 & 14.23 & $0.00 \%$ *** \\
\hline \multirow[t]{2}{*}{$\overline{\text { rvTXTOTAL }}$} & odr & -0.0025031 & 0.0037391 & -0.67 & $25.17 \%$ \\
\hline & Ils & 0.0024610 & 0.0016153 & 1.52 & $6.39 \%$ * \\
\hline \multirow[t]{2}{*}{ rvTXINCcor } & odr & 0.0178962 & 0.0121115 & 1.48 & $6.98 \%$ * \\
\hline & Ils & 0.0093894 & 0.0043028 & 2.18 & $1.46 \%$ *** \\
\hline \multirow[t]{2}{*}{ rvTXINCind } & odr & 0.0127397 & 0.0039577 & 3.22 & $0.07 \%^{* * *}$ \\
\hline & Ils & -0.0007078 & 0.0014570 & -0.49 & $31.36 \%$ \\
\hline \multirow[t]{2}{*}{ rvTXSALgen } & odr & 0.0100464 & 0.0041880 & 2.40 & $0.83 \%^{* * *}$ \\
\hline & Ils & 0.0004336 & 0.0012976 & 0.33 & $36.91 \%$ \\
\hline \multirow[t]{2}{*}{ rvTXPROP } & odr & 0.0127685 & 0.0043262 & 2.95 & $0.16 \%$ *** \\
\hline & Ils & 0.0097438 & 0.0014494 & 6.72 & $0.00 \%$ *** \\
\hline \multirow[t]{2}{*}{ rvTRFtot } & odr & 0.0194855 & 0.0057389 & 3.40 & $0.04 \%$ *** \\
\hline & Ils & -0.0077557 & 0.0025860 & -3.00 & $0.14 \%$ *** \\
\hline \multirow[t]{2}{*}{ rvTRFedu } & odr & 0.1577795 & 0.0217607 & 7.25 & $0.00 \%^{* * *}$ \\
\hline & Ils & 0.0443102 & 0.0087588 & 5.06 & $0.00 \%$ *** \\
\hline \multirow[t]{2}{*}{ rvTRFhwy } & odr & 0.0039490 & 0.0153767 & 0.26 & $39.87 \%$ \\
\hline & Ils & 0.0234687 & 0.0062073 & 3.78 & $0.01 \%$ *** \\
\hline \multirow[t]{2}{*}{ spEDUtot } & odr & -0.0287435 & 0.0044638 & -6.44 & $0.00 \%^{* * *}$ \\
\hline & Ils & -0.0081807 & 0.0020084 & -4.07 & $0.00 \%$ *** \\
\hline spHWYtot & odr & -0.0426024 & 0.0155098 & -2.75 & $0.30 \%$ *** \\
\hline & Ils & -0.0108664 & 0.0047621 & -2.28 & $1.13 \%$ *** \\
\hline spWELtot & odr & -0.0193764 & 0.0059203 & -3.27 & $0.05 \%$ *** \\
\hline & Ils & -0.0039471 & 0.0029446 & -1.34 & $9.01 \%$ * \\
\hline spCAPhwy & odr & 0.0149744 & 0.0185924 & 0.81 & $21.03 \%$ \\
\hline & Ils & -0.0022078 & 0.0064458 & -0.34 & $36.60 \%$ \\
\hline dmPOLgov & odr & -0.0010380 & 0.0008451 & -1.23 & $10.98 \%$ \\
\hline & Ils & -0.0022265 & 0.0005086 & -4.38 & $0.00 \%$ *** \\
\hline dmTXref & odr & -0.0017153 & 0.0011325 & -1.51 & $6.50 \%$ * \\
\hline & Ils & 0.0000856 & 0.0005383 & 0.16 & $43.68 \%$ \\
\hline dmTXsvl & odr & 0.0000085 & 0.0000774 & 0.11 & $45.61 \%$ \\
\hline & Ils & 0.0000588 & 0.0000208 & 2.83 & $0.24 \%$ *** \\
\hline $\mathrm{dmPOP}$ & odr & -0.0001841 & 0.0001553 & -1.19 & $11.80 \%$ \\
\hline & Ils & -0.0000097 & 0.0000355 & -0.27 & $39.20 \%$ \\
\hline dmDEN & odr & -0.0005325 & 0.0012430 & -0.43 & $33.42 \%$ \\
\hline & Ils & -0.0001418 & 0.0002607 & -0.54 & $29.32 \%$ \\
\hline dmWAGEcv & odr & -0.0116700 & 0.0124409 & -0.94 & $17.42 \%$ \\
\hline & Ils & -0.0236378 & 0.0041351 & -5.72 & $0.00 \%$ *** \\
\hline dmPRNFPcv & odr & 0.0064222 & 0.0102452 & 0.63 & $26.54 \%$ \\
\hline & Ils & 0.0071484 & 0.0028476 & 2.51 & $0.61 \%$ *** \\
\hline geHEtotP & odr & -0.5747542 & 0.1350808 & -4.25 & $0.00 \%$ *** \\
\hline & Ils & -0.2797150 & 0.0302948 & -9.23 & $0.00 \%$ *** \\
\hline geSIZ & odr & 0.0000497 & 0.0000235 & 2.12 & $1.73 \%$ *** \\
\hline & Ils & 0.0000221 & 0.0000039 & 5.61 & $0.00 \%$ *** \\
\hline geSIZPf & odr & -0.0000703 & 0.0000352 & -1.99 & $2.31 \%$ *** \\
\hline & Ils & -0.0000433 & 0.0000083 & -5.22 & $0.00 \% * * *$ \\
\hline geREGatl & odr & 0.0005882 & 0.0013128 & 0.45 & $32.71 \%$ \\
\hline & Ils & 0.0000483 & 0.0002643 & 0.18 & $42.74 \%$ \\
\hline
\end{tabular}


Table A3: Regression C, continued (per capita; 1959 - 1997)

\begin{tabular}{|c|c|c|c|c|c|}
\hline Variable & Method & Estimate & $\begin{array}{l}\text { Standard } \\
\text { Deviation }\end{array}$ & $\begin{array}{c}t \text {-value } \\
H_{0}: \theta_{i}=0 \\
H_{0}: \theta_{i} \neq 0\end{array}$ & $\begin{array}{c}\text { One-Sided } \\
\text { Marginal } \\
\text { Significance } \\
\text { Level }\end{array}$ \\
\hline 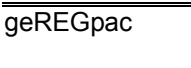 & $\begin{array}{l}\text { Odr } \\
\text { lls }\end{array}$ & $\begin{array}{r}-0.0019007 \\
0.0008022\end{array}$ & $\begin{array}{l}0.0019409 \\
0.0003446\end{array}$ & $\begin{array}{r}-0.98 \\
2.33\end{array}$ & $\begin{array}{l}16.38 \% \\
1.00 \% \text { *** }\end{array}$ \\
\hline$\overline{\text { gePOLCgov }}$ & $\begin{array}{l}\text { odr } \\
\text { lls }\end{array}$ & $\begin{array}{l}0.0005146 \\
0.0002152\end{array}$ & $\begin{array}{l}0.0001658 \\
0.0000312\end{array}$ & $\begin{array}{l}3.10 \\
6.89\end{array}$ & $\begin{array}{l}0.10 \%^{* * *} \\
0.00 \%^{* * *}\end{array}$ \\
\hline geSIZPw & $\begin{array}{l}\text { odr } \\
\text { lls }\end{array}$ & $\begin{array}{l}-0.0000131 \\
-0.0000133\end{array}$ & $\begin{array}{l}0.0000394 \\
0.0000088\end{array}$ & $\begin{array}{l}-0.33 \\
-1.51\end{array}$ & $\begin{array}{c}36.93 \% \\
6.53 \% \text { * }\end{array}$ \\
\hline geSIZPr & $\begin{array}{l}\text { odr } \\
\text { lls }\end{array}$ & $\begin{array}{l}-0.0000142 \\
-0.0000654 \\
\end{array}$ & $\begin{array}{l}0.0000505 \\
0.0000106 \\
\end{array}$ & $\begin{array}{l}-0.28 \\
-6.17 \\
\end{array}$ & $\begin{array}{l}38.93 \% \\
0.00 \% \text { *** }\end{array}$ \\
\hline geREGcan & $\begin{array}{l}\text { odr } \\
\text { lls }\end{array}$ & $\begin{array}{l}0.0020619 \\
0.0009324\end{array}$ & $\begin{array}{l}0.0010451 \\
0.0002225\end{array}$ & $\begin{array}{l}1.97 \\
4.19 \\
\end{array}$ & $\begin{array}{l}2.43 \%^{* * *} \\
0.00 \%^{* * *}\end{array}$ \\
\hline geREGmex & $\begin{array}{l}\text { odr } \\
\text { lls }\end{array}$ & $\begin{array}{l}-0.0094067 \\
-0.0041743\end{array}$ & $\begin{array}{l}0.0025413 \\
0.0004759\end{array}$ & $\begin{array}{l}-3.70 \\
-8.77\end{array}$ & $\begin{array}{l}0.01 \%^{* * *} \\
0.00 \%^{* * *}\end{array}$ \\
\hline$\overline{\text { gePOLallR }}$ & $\begin{array}{l}\text { odr } \\
\text { Ils }\end{array}$ & $\begin{array}{r}0.0002229 \\
-0.0000209\end{array}$ & $\begin{array}{l}0.0000990 \\
0.0000221\end{array}$ & $\begin{array}{r}2.25 \\
-0.95\end{array}$ & $\begin{array}{l}1.23 \% \text { *** } \\
17.15 \%\end{array}$ \\
\hline gePOLgov & $\begin{array}{l}\text { odr } \\
\text { Ils }\end{array}$ & $\begin{array}{l}-0.0000203 \\
-0.0000072\end{array}$ & $\begin{array}{l}0.0000497 \\
0.0000106\end{array}$ & $\begin{array}{l}-0.41 \\
-0.68\end{array}$ & $\begin{array}{l}34.17 \% \\
24.80 \% \\
\end{array}$ \\
\hline gePOLboth & $\begin{array}{l}\text { odr } \\
\text { lls }\end{array}$ & $\begin{array}{r}-0.0000219 \\
0.0001044\end{array}$ & $\begin{array}{l}0.0000478 \\
0.0000143\end{array}$ & $\begin{array}{r}-0.46 \\
7.32 \\
\end{array}$ & $\begin{array}{l}32.36 \% \\
0.00 \% \text { *** }\end{array}$ \\
\hline$\overline{\text { gePOLCallR }}$ & $\begin{array}{l}\text { odr } \\
\text { lls }\end{array}$ & $\begin{array}{l}-0.0005000 \\
-0.0003202\end{array}$ & $\begin{array}{l}0.0002561 \\
0.0000430\end{array}$ & $\begin{array}{l}-1.95 \\
-7.44\end{array}$ & $\begin{array}{l}2.55 \%^{* *} \\
0.00 \%^{* * *}\end{array}$ \\
\hline gePOLCboth & $\begin{array}{l}\text { odr } \\
\text { lls }\end{array}$ & $\begin{array}{l}0.0002060 \\
0.0000306\end{array}$ & $\begin{array}{l}0.0001670 \\
0.0000319\end{array}$ & $\begin{array}{l}1.23 \\
0.96 \\
\end{array}$ & $\begin{array}{l}10.88 \% \\
16.90 \%\end{array}$ \\
\hline dmDENsq & $\begin{array}{l}\text { odr } \\
\text { lls }\end{array}$ & $\begin{array}{l}-0.0000353 \\
-0.0000147 \\
\end{array}$ & $\begin{array}{l}0.0001087 \\
0.0000244 \\
\end{array}$ & $\begin{array}{l}-0.32 \\
-0.60 \\
\end{array}$ & $\begin{array}{l}37.27 \% \\
27.29 \% \\
\end{array}$ \\
\hline dmPOLallR & $\begin{array}{l}\text { odr } \\
\text { lls }\end{array}$ & $\begin{array}{r}-0.0013788 \\
0.0043822 \\
\end{array}$ & $\begin{array}{l}0.0017298 \\
0.0010388 \\
\end{array}$ & $\begin{array}{r}-0.80 \\
4.22 \\
\end{array}$ & $\begin{array}{l}21.28 \% \\
0.00 \% \text { *** }\end{array}$ \\
\hline dmPOLboth & $\begin{array}{l}\text { odr } \\
\text { lls }\end{array}$ & $\begin{array}{r}0.0011429 \\
-0.0046978 \\
\end{array}$ & $\begin{array}{l}0.0015565 \\
0.0008205 \\
\end{array}$ & $\begin{array}{r}0.73 \\
-5.73 \\
\end{array}$ & $\begin{array}{l}23.14 \% \\
0.00 \% \text { *** }\end{array}$ \\
\hline dmISNFPcv & $\begin{array}{l}\text { odr } \\
\text { Ils }\end{array}$ & $\begin{array}{l}-0.0144514 \\
-0.0067683\end{array}$ & $\begin{array}{l}0.0072304 \\
0.0018157\end{array}$ & $\begin{array}{l}-2.00 \\
-3.73\end{array}$ & $\begin{array}{l}2.29 \%^{* * *} \\
0.01 \% \text { *** }\end{array}$ \\
\hline dmISFEDpc & $\begin{array}{l}\text { odr } \\
\text { Ils }\end{array}$ & $\begin{array}{l}-0.0019222 \\
-0.0024400\end{array}$ & $\begin{array}{l}0.0013498 \\
0.0004793\end{array}$ & $\begin{array}{l}-1.42 \\
-5.09\end{array}$ & $\begin{array}{l}7.73 \%^{*} \\
0.00 \% \text { *** }\end{array}$ \\
\hline dmPRNFPman & $\begin{array}{l}\text { odr } \\
\text { Ils }\end{array}$ & $\begin{array}{r}-0.0000585 \\
-0.0000456\end{array}$ & $\begin{array}{l}0.0001426 \\
0.0000328\end{array}$ & $\begin{array}{l}-0.41 \\
-1.39\end{array}$ & $\begin{array}{c}34.08 \% \\
8.22 \% \text { * }\end{array}$ \\
\hline dmPRNFPtpu & $\begin{array}{l}\text { odr } \\
\text { lls }\end{array}$ & $\begin{array}{r}-0.0012225 \\
-0.0010796 \\
\end{array}$ & $\begin{array}{l}0.0007173 \\
0.0001606 \\
\end{array}$ & $\begin{array}{l}-1.70 \\
-6.72 \\
\end{array}$ & $\begin{array}{l}4.43 \%^{* *} \\
0.00 \%^{* * *}\end{array}$ \\
\hline dmPRNFPser & $\begin{array}{l}\text { odr } \\
\text { Ils }\end{array}$ & $\begin{array}{r}0.0000614 \\
-0.0001070\end{array}$ & $\begin{array}{l}0.0002306 \\
0.0000518\end{array}$ & $\begin{array}{r}0.27 \\
-2.07\end{array}$ & $\begin{array}{l}39.51 \% \\
1.94 \% \text { *** }\end{array}$ \\
\hline$\overline{\overline{\mathrm{R}^{2}}}$ & $\begin{array}{l}\text { odr } \\
\text { Ils }\end{array}$ & $\begin{array}{l}99.9 \\
98.3 \\
\end{array}$ & & & \\
\hline$\overline{\ell(\cdot)}$ & $\begin{array}{l}\text { odr } \\
\text { Ils }\end{array}$ & $\begin{array}{r}-9695.6 \\
-11641.3 \\
\end{array}$ & & & \\
\hline$\sigma_{\varepsilon}$ & $\begin{array}{l}\text { odr } \\
\text { nls } \\
\text { Ils }\end{array}$ & $\begin{array}{c}161.0 \\
702.6 \\
0.03953\end{array}$ & & & \\
\hline$\sigma_{\varepsilon_{y}}$ & $\begin{array}{l}\text { odr } \\
\text { Ils }\end{array}$ & $\begin{array}{l}162.9 \\
\mathrm{Na}\end{array}$ & & & \\
\hline $\begin{array}{l}\sigma_{\varepsilon} \\
y_{t 0}\end{array}$ & $\begin{array}{l}\text { odr } \\
\text { lls }\end{array}$ & $\begin{array}{l}50.8 \\
\mathrm{Na} \\
\end{array}$ & & & \\
\hline$\sigma_{\varepsilon}$ & $\begin{array}{l}\text { odr } \\
\text { Ils }\end{array}$ & $\begin{array}{l}0.00843 \\
\mathrm{Na}\end{array}$ & & & \\
\hline
\end{tabular}

*** indicates $\mathrm{H}_{0}$ is rejected at $\alpha=5 \%$ significance level.

** indicates $\mathrm{H}_{0}$ is rejected at $\alpha=10 \%$ significance level.

* indicates $\mathrm{H}_{0}$ is rejected at $\alpha=20 \%$ significance level.

${ }^{a} \ell(\cdot)$ denotes the value of the likehood function. $\left[\sigma_{\varepsilon}, \sigma_{\varepsilon y}, \sigma_{\varepsilon y t 0}, \sigma_{\gamma}\right]$ denotes the standard deviations of the estimated residuals, the measurement error of income, the measurement error for initial income $\mathrm{y}_{0}$, and the model, respectively; the standard deviation $\sigma_{\varepsilon}$ is a weighted average of the measurement error standard deviations and the model standard deviation. 
Table A4: Regression D (per capita; 1959 - 1997)

\begin{tabular}{|c|c|c|c|c|c|}
\hline Variable & Method & Estimate & $\begin{array}{l}\text { Standard } \\
\text { Deviation }\end{array}$ & $\begin{array}{c}t \text {-value } \\
H_{0}: \theta_{i}=0 \\
H_{0}: \theta_{i} \neq 0\end{array}$ & $\begin{array}{c}\text { One-Sided } \\
\text { Marginal } \\
\text { Significance } \\
\text { Level }\end{array}$ \\
\hline \multirow[t]{2}{*}{ usGRW } & odr & 0.9056973 & 0.0310002 & 29.22 & $0.00 \%$ *** \\
\hline & Ils & 0.7972571 & 0.0469863 & 16.97 & $0.00 \%$ *** \\
\hline \multirow[t]{2}{*}{ usINF } & odr & -0.0007685 & 0.0001910 & -4.02 & $0.00 \%$ *** \\
\hline & Ils & 0.0001856 & 0.0001211 & 1.53 & $6.29 \%$ * \\
\hline \multirow[t]{2}{*}{ usFUELpp } & odr & -0.0026697 & 0.0004488 & -5.95 & $0.00 \%$ *** \\
\hline & Ils & -0.0012525 & 0.0003493 & -3.59 & $0.02 \%$ *** \\
\hline \multirow[t]{2}{*}{ geREGcon } & odr & 0.0244796 & 0.0060740 & 4.03 & $0.00 \%^{* * *}$ \\
\hline & Ils & 0.0304117 & 0.0019761 & 15.39 & $0.00 \%$ *** \\
\hline \multirow[t]{2}{*}{ gePOLstate } & odr & 0.0029490 & 0.0009897 & 2.98 & $0.15 \%^{* * *}$ \\
\hline & Ils & 0.0019421 & 0.0001870 & 10.39 & $0.00 \%$ *** \\
\hline \multirow[t]{2}{*}{$\overline{y_{0}}$} & odr & 0.0007136 & 0.0003578 & 1.99 & $2.31 \%^{* * *}$ \\
\hline & Ils & -0.0016088 & 0.0000900 & -17.88 & $0.00 \%$ *** \\
\hline \multirow[t]{2}{*}{ rho } & odr & 0.0102350 & 0.0015342 & 6.67 & $0.00 \%$ *** \\
\hline & Ils & 0.0057333 & 0.0004827 & 11.88 & $0.00 \%$ *** \\
\hline \multirow[t]{2}{*}{ rvTXTOTAL } & odr & 0.0026112 & 0.0031381 & 0.83 & $20.27 \%$ \\
\hline & Ils & 0.0035484 & 0.0013141 & 2.70 & $0.35 \%$ *** \\
\hline \multirow[t]{2}{*}{ rvTXINCcor } & odr & 0.0141929 & 0.0111683 & 1.27 & $10.20 \%$ \\
\hline & Ils & 0.0089559 & 0.0033751 & 2.65 & $0.40 \%$ *** \\
\hline \multirow[t]{2}{*}{ rvTXINCind } & odr & 0.0071333 & 0.0034335 & 2.08 & $1.89 \%$ *** \\
\hline & Ils & 0.0002430 & 0.0011205 & 0.22 & $41.42 \%$ \\
\hline \multirow[t]{2}{*}{$\overline{\text { rvTXSALgen }}$} & odr & 0.0094404 & 0.0038200 & 2.47 & $0.68 \%$ *** \\
\hline & Ils & 0.0015895 & 0.0011734 & 1.35 & $8.79 \%$ * \\
\hline \multirow[t]{2}{*}{ rvTXPROP } & odr & 0.0076110 & 0.0036958 & 2.06 & $1.98 \%$ *** \\
\hline & Ils & 0.0056863 & 0.0012133 & 4.69 & $0.00 \%$ *** \\
\hline \multirow[t]{2}{*}{ rvTRFtot } & odr & 0.0163649 & 0.0051305 & 3.19 & $0.07 \%^{* * *}$ \\
\hline & Ils & -0.0035224 & 0.0019897 & -1.77 & $3.84 \%$ ** \\
\hline \multirow[t]{2}{*}{ rvTRFedu } & odr & 0.1434074 & 0.0198415 & 7.23 & $0.00 \%$ *** \\
\hline & Ils & 0.0135373 & 0.0073900 & 1.83 & $3.36 \%$ ** \\
\hline \multirow[t]{2}{*}{ rvTRFhwy } & odr & 0.0096521 & 0.0134350 & 0.72 & $23.63 \%$ \\
\hline & Ils & 0.0019826 & 0.0048001 & 0.41 & $33.98 \%$ \\
\hline \multirow[t]{2}{*}{ spEDUtot } & odr & -0.0249903 & 0.0037683 & -6.63 & $0.00 \%$ *** \\
\hline & Ils & -0.0061459 & 0.0014506 & -4.24 & $0.00 \%$ *** \\
\hline \multirow[t]{2}{*}{ spHWYtot } & odr & -0.0392720 & 0.0134587 & -2.92 & $0.18 \%$ *** \\
\hline & Ils & -0.0189576 & 0.0041434 & -4.58 & $0.00 \%$ *** \\
\hline \multirow[t]{2}{*}{ spWELtot } & odr & -0.0143939 & 0.0050963 & -2.82 & $0.24 \%$ *** \\
\hline & Ils & 0.0004317 & 0.0021893 & 0.20 & $42.19 \%$ \\
\hline \multirow{2}{*}{ spCAPhwy } & $o d r$ & 0.0099874 & 0.0159443 & 0.63 & $26.56 \%$ \\
\hline & Ils & 0.0176750 & 0.0052652 & 3.36 & $0.04 \%$ *** \\
\hline
\end{tabular}


Table A4: Regression D, continued (per capita; 1959 - 1997)

\begin{tabular}{|c|c|c|c|c|c|}
\hline Variable & Method & Estimate & $\begin{array}{l}\text { Standard } \\
\text { Deviation }\end{array}$ & $\begin{array}{c}t \text {-value } \\
H_{0}: \theta_{i}=0 \\
H_{0}: \theta_{i} \neq 0\end{array}$ & $\begin{array}{c}\text { One-Sided } \\
\text { Marginal } \\
\text { Significance } \\
\text { Level }\end{array}$ \\
\hline \multirow[t]{2}{*}{ dmPOLgov } & odr & -0.0010235 & 0.0007508 & -1.36 & $8.65 \%$ * \\
\hline & Ils & -0.0016824 & 0.0003849 & -4.37 & $0.00 \%$ *** \\
\hline \multirow[t]{2}{*}{ dmTXref } & odr & -0.0015992 & 0.0010437 & -1.53 & $6.28 \%$ * \\
\hline & Ils & -0.0010759 & 0.0004708 & -2.29 & $1.12 \%$ *** \\
\hline \multirow[t]{2}{*}{ dmTXsvl } & odr & -0.0001107 & 0.0000693 & -1.60 & $5.53 \%$ * \\
\hline & Ils & -0.0000242 & 0.0000197 & -1.23 & $11.01 \%$ \\
\hline \multirow[t]{2}{*}{ dmPOP } & odr & -0.0002824 & 0.0001148 & -2.46 & $0.70 \%$ *** \\
\hline & Ils & -0.0001299 & 0.0000274 & -4.75 & $0.00 \%$ *** \\
\hline \multirow[t]{2}{*}{ dmDEN } & odr & -0.0011047 & 0.0002829 & -3.90 & $0.00 \%$ *** \\
\hline & Ils & -0.0004231 & 0.0000603 & -7.02 & $0.00 \%$ *** \\
\hline \multirow[t]{2}{*}{ dmWAGEcv } & odr & 0.0154413 & 0.0102397 & 1.51 & $6.59 \%$ * \\
\hline & Ils & -0.0165814 & 0.0034684 & -4.78 & $0.00 \%$ *** \\
\hline \multirow[t]{2}{*}{ dmPRNFPcv } & odr & -0.0071238 & 0.0032788 & -2.17 & $1.50 \%$ *** \\
\hline & Ils & -0.0015837 & 0.0007087 & -2.23 & $1.28 \%$ *** \\
\hline \multirow[t]{2}{*}{ geHEtotP } & odr & -0.2951371 & 0.0972264 & -3.04 & $0.12 \%$ *** \\
\hline & Ils & -0.1513898 & 0.0210277 & -7.20 & $0.00 \%$ *** \\
\hline \multirow[t]{2}{*}{ geSIZ } & odr & 0.0000054 & 0.0000115 & 0.47 & $31.86 \%$ \\
\hline & Ils & -0.0000050 & 0.0000023 & -2.15 & $1.57 \%$ *** \\
\hline \multirow[t]{2}{*}{ geSIZPf } & odr & -0.0000626 & 0.0000254 & -2.46 & $0.70 \%$ *** \\
\hline & Ils & -0.0000201 & 0.0000057 & -3.54 & $0.02 \%$ *** \\
\hline \multirow[t]{2}{*}{ geREGatl } & odr & 0.0013876 & 0.0009819 & 1.41 & $7.89 \%$ * \\
\hline & Ils & 0.0007583 & 0.0001852 & 4.09 & $0.00 \%$ *** \\
\hline \multirow[t]{2}{*}{ geREGpac } & odr & -0.0027652 & 0.0015502 & -1.78 & $3.73 \%$ ** \\
\hline & Ils & 0.0011817 & 0.0003036 & 3.89 & $0.01 \%$ *** \\
\hline \multirow[t]{2}{*}{ gePOLCgov } & odr & 0.0001881 & 0.0001157 & 1.62 & $5.22 \%$ * \\
\hline & Ils & 0.0000565 & 0.0000213 & 2.65 & $0.41 \%$ *** \\
\hline \multirow{2}{*}{$\overline{\mathrm{R}^{2}}$} & odr & 99.9 & & & \\
\hline & Ils & 97.9 & & & \\
\hline \multirow[t]{2}{*}{$\ell(\cdot)$} & odr & -9712.0 & & & \\
\hline & IIS & -11845.7 & & & \\
\hline \multirow[t]{3}{*}{$\overline{\sigma_{\varepsilon}}$} & odr & 161.2 & & & \\
\hline & nls & 788.3 & & & \\
\hline & Ils & 0.0 & & & \\
\hline \multirow{2}{*}{$\sigma_{\varepsilon}$} & odr & 163.1 & & & \\
\hline & Ils & na & & & \\
\hline \multirow{2}{*}{$\sigma_{\mathrm{y}_{\mathrm{t} 0}}$} & odr & 49.5 & & & \\
\hline & Ils & na & & & \\
\hline \multirow{2}{*}{$\sigma_{\varepsilon}$} & odr & 0.00857 & & & \\
\hline & Ils & na & & & \\
\hline
\end{tabular}

*** indicates $\mathrm{H}_{0}$ is rejected at $\alpha=5 \%$ significance level.

** indicates $\mathrm{H}_{0}$ is rejected at $\alpha=10 \%$ significance level.

* indicates $\mathrm{H}_{0}$ is rejected at $\alpha=20 \%$ significance level.

${ }^{a} \ell(\cdot)$ denotes the value of the likehood function. $\left[\sigma_{\varepsilon}, \sigma_{\varepsilon y}, \sigma_{\varepsilon y t 0}, \sigma_{\gamma}\right]$ denotes the standard deviations of the estimated residuals, the measurement error of income, the measurement error for initial income $\mathrm{y}_{0}$, and the model, respectively; the standard deviation $\sigma_{\varepsilon}$ is a weighted average of the measurement error standard deviations and the model standard deviation. 
Table A5: Regression E (per capita; 1959 - 1997) ${ }^{\mathrm{a}}$

\begin{tabular}{|c|c|c|c|c|c|}
\hline Variable & Method & Estimate & $\begin{array}{l}\text { Standard } \\
\text { Deviation }\end{array}$ & $\begin{array}{c}t \text {-value } \\
H_{0}: \theta_{i}=0 \\
H_{0}: \theta_{i} \neq 0\end{array}$ & $\begin{array}{c}\text { One-Sided } \\
\text { Marginal } \\
\text { Significance } \\
\text { Level }\end{array}$ \\
\hline \multirow[t]{2}{*}{ usGRW } & odr & 0.8941966 & 0.0259472 & 34.46 & $0.00 \%$ *** \\
\hline & Ils & 0.7882297 & 0.0447913 & 17.60 & $0.00 \%^{* * *}$ \\
\hline \multirow[t]{2}{*}{ usINF } & odr & -0.0006625 & 0.0001581 & -4.19 & $0.00 \%$ *** \\
\hline & Ils & 0.0000764 & 0.0001154 & 0.66 & $25.39 \%$ \\
\hline \multirow[t]{2}{*}{ usFUELpp } & odr & -0.0024169 & 0.0003768 & -6.42 & $0.00 \%^{* * *}$ \\
\hline & Ils & -0.0006407 & 0.0003391 & -1.89 & $2.95 \%$ ** \\
\hline \multirow[t]{2}{*}{ geREGcon } & odr & 0.0241684 & 0.0052393 & 4.61 & $0.00 \%^{* * *}$ \\
\hline & Ils & 0.0313777 & 0.0019052 & 16.47 & $0.00 \%$ *** \\
\hline \multirow[t]{2}{*}{ gePOLstate } & odr & 0.0029203 & 0.0007982 & 3.66 & $0.01 \%^{* * *}$ \\
\hline & Ils & 0.0014977 & 0.0001815 & 8.25 & $0.00 \%$ *** \\
\hline \multirow[t]{2}{*}{$\overline{y_{0}}$} & odr & 0.0006289 & 0.0003001 & 2.10 & $1.81 \%^{* * *}$ \\
\hline & Ils & -0.0019079 & 0.0000901 & -21.18 & $0.00 \%$ *** \\
\hline \multirow[t]{2}{*}{ rho } & odr & 0.0125412 & 0.0022004 & 5.70 & $0.00 \%$ *** \\
\hline & Ils & 0.0038473 & 0.0009959 & 3.86 & $0.01 \%$ *** \\
\hline \multirow[t]{2}{*}{ rvTXTOTAL } & odr & 0.0033259 & 0.0025739 & 1.29 & $9.82 \%$ * \\
\hline & Ils & 0.0096244 & 0.0012998 & 7.40 & $0.00 \%$ *** \\
\hline \multirow[t]{2}{*}{ rvTXINCcor } & odr & 0.0191038 & 0.0092603 & 2.06 & $1.96 \%$ *** \\
\hline & Ils & 0.0148150 & 0.0032494 & 4.56 & $0.00 \%$ *** \\
\hline \multirow[t]{2}{*}{ rvTXINCind } & odr & 0.0061610 & 0.0028659 & 2.15 & $1.59 \%$ *** \\
\hline & Ils & -0.0058435 & 0.0011023 & -5.30 & $0.00 \%$ *** \\
\hline \multirow[t]{2}{*}{$\overline{\text { rvTXSALgen }}$} & odr & 0.0085303 & 0.0032497 & 2.62 & $0.44 \%$ *** \\
\hline & Ils & -0.0063593 & 0.0011902 & -5.34 & $0.00 \%$ *** \\
\hline \multirow[t]{2}{*}{ rvTXPROP } & odr & 0.0058981 & 0.0030853 & 1.91 & $2.81 \%^{* *}$ \\
\hline & Ils & 0.0056219 & 0.0011968 & 4.70 & $0.00 \%$ *** \\
\hline \multirow[t]{2}{*}{ rvTRFtot } & odr & 0.0194984 & 0.0042902 & 4.54 & $0.00 \%^{* * *}$ \\
\hline & Ils & -0.0121337 & 0.0020793 & -5.84 & $0.00 \%$ *** \\
\hline \multirow[t]{2}{*}{ rvTRFedu } & odr & 0.1102266 & 0.0165482 & 6.66 & $0.00 \%$ *** \\
\hline & Ils & 0.0231872 & 0.0070103 & 3.31 & $0.05 \%$ *** \\
\hline \multirow[t]{2}{*}{ rvTRFhwy } & odr & 0.0152703 & 0.0115671 & 1.32 & $9.35 \%$ * \\
\hline & Ils & 0.0505584 & 0.0056351 & 8.97 & $0.00 \%$ *** \\
\hline \multirow[t]{2}{*}{ spEDUtot } & odr & -0.0239896 & 0.0031166 & -7.70 & $0.00 \%$ *** \\
\hline & Ils & -0.0073666 & 0.0013638 & -5.40 & $0.00 \%$ *** \\
\hline \multirow[t]{2}{*}{ spHWYtot } & odr & -0.0392916 & 0.0116252 & -3.38 & $0.04 \%$ *** \\
\hline & Ils & -0.0438618 & 0.0044079 & -9.95 & $0.00 \%$ *** \\
\hline \multirow[t]{2}{*}{ spWELtot } & odr & -0.0158056 & 0.0041751 & -3.79 & $0.01 \%$ *** \\
\hline & Ils & 0.0011201 & 0.0020451 & 0.55 & $29.20 \%$ \\
\hline \multirow{2}{*}{ spCAPhwy } & $o d r$ & 0.0023492 & 0.0133271 & 0.18 & $43.01 \%$ \\
\hline & Ils & 0.0241478 & 0.0049008 & 4.93 & $0.00 \%$ *** \\
\hline
\end{tabular}


Table A5: Regression E, continued (per capita; 1959 - 1997)

\begin{tabular}{|c|c|c|c|c|c|}
\hline Variable & Method & Estimate & $\begin{array}{l}\text { Standard } \\
\text { Deviation }\end{array}$ & $\begin{array}{c}t \text {-value } \\
H_{0}: \theta_{i}=0 \\
H_{0}: \theta_{i} \neq 0\end{array}$ & $\begin{array}{c}\text { One-Sided } \\
\text { Marginal } \\
\text { Significance } \\
\text { Level }\end{array}$ \\
\hline \multirow[t]{2}{*}{ dmPOLgov } & odr & -0.0010039 & 0.0006423 & "-1.56 & $5.91 \%$ * \\
\hline & Ils & -0.0025221 & 0.0004092 & -6.16 & $0.00 \%$ *** \\
\hline \multirow[t]{2}{*}{ dmTXref } & odr & -0.0020151 & 0.0008639 & -2.33 & $0.99 \%$ *** \\
\hline & Ils & -0.0021147 & 0.0004412 & -4.79 & $0.00 \%$ *** \\
\hline \multirow[t]{2}{*}{ dmTXsvl } & odr & -0.0000889 & 0.0000602 & -1.48 & $7.02 \%$ * \\
\hline & Ils & -0.0000064 & 0.0000189 & -0.34 & $36.81 \%$ \\
\hline \multirow[t]{2}{*}{ dmPOP } & odr & -0.0003357 & 0.0000947 & -3.55 & $0.02 \%$ *** \\
\hline & Ils & -0.0002163 & 0.0000256 & -8.46 & $0.00 \% * * *$ \\
\hline \multirow[t]{2}{*}{ dmDEN } & odr & -0.0010525 & 0.0002390 & -4.40 & $0.00 \%$ *** \\
\hline & Ils & -0.0005401 & 0.0000630 & -8.57 & $0.00 \%$ *** \\
\hline \multirow[t]{2}{*}{ dmWAGEcv } & odr & 0.0168584 & 0.0085853 & 1.96 & $2.49 \%$ *** \\
\hline & Ils & -0.0017786 & 0.0036264 & -0.49 & $31.19 \%$ \\
\hline \multirow[t]{2}{*}{ dmPRNFPcv } & odr & -0.0074348 & 0.0027768 & -2.68 & $0.37 \%$ *** \\
\hline & Ils & -0.0023562 & 0.0006987 & -3.37 & $0.04 \%$ *** \\
\hline \multirow[t]{2}{*}{ geHEtotP } & odr & -0.2687828 & 0.0783004 & -3.43 & $0.03 \%$ *** \\
\hline & Ils & -0.1821162 & 0.0197325 & -9.23 & $0.00 \%$ *** \\
\hline \multirow[t]{2}{*}{$\overline{\text { geSIZ }}$} & odr & 0.0000150 & 0.0000101 & 1.49 & $6.78 \%$ * \\
\hline & Ils & 0.0000020 & 0.0000023 & 0.88 & $18.89 \%$ \\
\hline \multirow[t]{2}{*}{ geSIZPf } & odr & -0.0000631 & 0.0000218 & -2.90 & $0.19 \%$ *** \\
\hline & Ils & -0.0000630 & 0.0000061 & -10.36 & $0.00 \%$ *** \\
\hline \multirow[t]{2}{*}{ geREGatl } & odr & 0.0015145 & 0.0008066 & 1.88 & $3.03 \%$ ** \\
\hline & Ils & 0.0004304 & 0.0001724 & 2.50 & $0.63 \%$ *** \\
\hline \multirow[t]{2}{*}{ geREGpac } & odr & -0.0022791 & 0.0012560 & -1.81 & $3.49 \%$ ** \\
\hline & Ils & 0.0022308 & 0.0002926 & 7.62 & $0.00 \% * * *$ \\
\hline \multirow[t]{2}{*}{ gePOLCgov } & odr & 0.0001719 & 0.0001023 & 1.68 & $4.65 \%$ ** \\
\hline & Ils & -0.0000013 & 0.0000226 & -0.06 & $47.74 \%$ \\
\hline \multirow{2}{*}{$\overline{\mathrm{R}^{2}}$} & odr & 99.9 & & & \\
\hline & Ils & 98.3 & & & \\
\hline \multirow[t]{2}{*}{$\overline{\ell(\cdot)}$} & odr & -8325.9 & & & \\
\hline & Ils & -10468.1 & & & \\
\hline \multirow[t]{3}{*}{$\sigma_{\varepsilon}$} & odr & 108.2 & & & \\
\hline & nls & 723.2 & & & \\
\hline & Ils & 0.0 & & & \\
\hline \multirow{2}{*}{$\sigma_{\varepsilon}$} & odr & 109.4 & & & \\
\hline & Ils & na & & & \\
\hline \multirow{2}{*}{$\sigma_{\varepsilon}$} & odr & 48.3 & & & \\
\hline & Ils & na & & & \\
\hline \multirow{2}{*}{$\sigma_{\varepsilon}$} & odr & 0.00761 & & & \\
\hline & Ils & na & & & \\
\hline
\end{tabular}

*** indicates $\mathrm{H}_{0}$ is rejected at $\alpha=5 \%$ significance level.

** indicates $\mathrm{H}_{0}$ is rejected at $\alpha=10 \%$ significance level.

* indicates $\mathrm{H}_{0}$ is rejected at $\alpha=20 \%$ significance level.

${ }^{a} \ell(\cdot)$ denotes the value of the likehood function. $\left[\sigma_{\varepsilon}, \sigma_{\varepsilon y}, \sigma_{\varepsilon y t 0}, \sigma_{\gamma}\right]$ denotes the standard deviations of the estimated residuals, the measurement error of income, the measurement error for initial income $\mathrm{y}_{0}$, and the model, respectively; the standard deviation $\sigma_{\varepsilon}$ is a weighted average of the measurement error standard deviations and the model standard deviation. 
Table A6: Regression F (per capita; 1977 - 1997) ${ }^{\mathrm{a}}$

\begin{tabular}{|c|c|c|c|c|c|}
\hline Variable & Method & Estimate & $\begin{array}{l}\text { Standard } \\
\text { Deviation }\end{array}$ & $\begin{array}{c}t \text {-value } \\
H_{0}: \theta_{i}=0 \\
H_{0}: \theta_{i} \neq 0\end{array}$ & $\begin{array}{c}\text { One-Sided } \\
\text { Marginal } \\
\text { Significance } \\
\text { Level }\end{array}$ \\
\hline \multirow[t]{2}{*}{ usGRW } & odr & 0.8376702 & 0.0349663 & 23.96 & $0.00 \%$ *** \\
\hline & Ils & 0.8512821 & 0.0598304 & 14.23 & $0.00 \%$ *** \\
\hline \multirow[t]{2}{*}{ usINF } & odr & -0.0014890 & 0.0002419 & -6.16 & $0.00 \%$ *** \\
\hline & Ils & -0.0004682 & 0.0001943 & -2.41 & $0.81 \%$ *** \\
\hline \multirow[t]{2}{*}{ usFUELpp } & odr & -0.0038336 & 0.0005868 & $\begin{array}{l}-6.53 \\
\end{array}$ & $0.00 \%$ *** \\
\hline & Ils & -0.0024630 & 0.0006297 & -3.91 & $0.00 \% * * *$ \\
\hline \multirow[t]{2}{*}{ geREGcon } & odr & -0.0016251 & 0.0096351 & -0.17 & $43.31 \%$ \\
\hline & Ils & 0.0191752 & 0.0036605 & 5.24 & $0.00 \%$ *** \\
\hline \multirow[t]{2}{*}{ gePOLstate } & odr & 0.0077262 & 0.0011849 & 6.52 & $0.00 \%$ *** \\
\hline & Ils & 0.0056481 & 0.0003525 & 16.02 & $0.00 \%$ *** \\
\hline \multirow[t]{2}{*}{$\overline{y_{0}}$} & odr & 0.0042018 & 0.0004824 & 8.71 & $0.00 \%$ *** \\
\hline & Ils & 0.0009721 & 0.0002343 & 4.15 & $0.00 \%$ *** \\
\hline \multirow[t]{2}{*}{ rho } & odr & 0.0133331 & 0.0018369 & 7.26 & $0.00 \%$ *** \\
\hline & Ils & 0.0128239 & 0.0012559 & 10.21 & $0.00 \%$ *** \\
\hline \multirow[t]{2}{*}{ rvTXTOTAL } & odr & -0.0122890 & 0.0035545 & -3.46 & $0.03 \%$ *** \\
\hline & Ils & -0.0033020 & 0.0019240 & -1.72 & $4.33 \%$ ** \\
\hline \multirow[t]{2}{*}{ rvTXINCcor } & odr & 0.0144542 & 0.0118043 & 1.22 & $11.06 \%$ \\
\hline & Ils & 0.0161289 & 0.0047851 & 3.37 & $0.04 \%$ *** \\
\hline \multirow[t]{2}{*}{ rvTXINCind } & odr & 0.0124757 & 0.0035013 & 3.56 & $0.02 \%$ *** \\
\hline & Ils & 0.0039419 & 0.0013969 & 2.82 & $0.24 \% * * *$ \\
\hline \multirow[t]{2}{*}{ rvTXSALgen } & odr & 0.0161361 & 0.0044950 & 3.59 & $0.02 \%$ *** \\
\hline & Ils & 0.0078923 & 0.0018746 & 4.21 & $0.00 \%$ *** \\
\hline \multirow[t]{2}{*}{ rvTXPROP } & odr & 0.0095557 & 0.0043592 & 2.19 & $1.43 \%$ *** \\
\hline & Ils & -0.0003816 & 0.0019071 & -0.20 & $42.07 \%$ \\
\hline \multirow[t]{2}{*}{ rvTRFtot } & odr & 0.0362070 & 0.0052005 & 6.96 & $0.00 \%^{* * *}$ \\
\hline & Ils & 0.0031477 & 0.0026302 & 1.20 & $11.59 \%$ \\
\hline \multirow[t]{2}{*}{ rvTRFedu } & odr & 0.0928111 & 0.0263119 & 3.53 & $0.02 \%$ *** \\
\hline & Ils & 0.0185087 & 0.0135811 & 1.36 & $8.67 \%$ * \\
\hline \multirow[t]{2}{*}{ rvTRFhwy } & odr & -0.0698818 & 0.0204263 & -3.42 & $0.03 \%$ *** \\
\hline & Ils & -0.0329248 & 0.0103197 & -3.19 & $0.07 \%$ *** \\
\hline \multirow[t]{2}{*}{ spEDUtot } & odr & -0.0234398 & 0.0043689 & -5.37 & $0.00 \%$ *** \\
\hline & Ils & -0.0067020 & 0.0021507 & -3.12 & $0.09 \%$ *** \\
\hline \multirow[t]{2}{*}{ spHWYtot } & odr & -0.0029209 & 0.0155761 & -0.19 & $42.56 \%$ \\
\hline & Ils & 0.0479920 & 0.0081786 & 5.87 & $0.00 \%$ *** \\
\hline \multirow[t]{2}{*}{ spWELtot } & odr & -0.0171348 & 0.0052951 & -3.24 & $0.06 \%$ *** \\
\hline & Ils & -0.0012613 & 0.0031669 & -0.40 & $34.53 \%$ \\
\hline \multirow[t]{2}{*}{ spCAPhwy } & odr & -0.0395652 & 0.0170140 & -2.33 & $1.02 \%^{* \star *}$ \\
\hline & Ils & -0.0761338 & 0.0073646 & -10.34 & $0.00 \%$ *** \\
\hline
\end{tabular}


Table A6: Regression F, continued (per capita; 1977 - 1997)

\begin{tabular}{|c|c|c|c|c|c|}
\hline Variable & Method & Estimate & $\begin{array}{l}\text { Standard } \\
\text { Deviation }\end{array}$ & $\begin{array}{c}t \text {-value } \\
H_{0}: \theta_{i}=0 \\
H_{0}: \theta_{i} \neq 0\end{array}$ & $\begin{array}{c}\text { One-Sided } \\
\text { Marginal } \\
\text { Significance } \\
\text { Level }\end{array}$ \\
\hline \multirow[t]{2}{*}{ dmPOLgov } & odr & -0.0017111 & 0.0008823 & -1.94 & $2.64 \%$ ** \\
\hline & Ils & -0.0007516 & 0.0005810 & -1.29 & $9.81 \%$ * \\
\hline \multirow[t]{2}{*}{ dmTXref } & odr & -0.0028185 & 0.0010270 & -2.74 & $0.31 \%$ *** \\
\hline & Ils & -0.0009378 & 0.0004808 & -1.95 & $2.57 \%$ ** \\
\hline \multirow[t]{2}{*}{ dmTXsvl } & odr & 0.0000372 & 0.0001121 & 0.33 & $37.00 \%$ \\
\hline & Ils & -0.0000658 & 0.0000448 & -1.47 & $7.09 \%$ * \\
\hline \multirow[t]{2}{*}{ dmPOP } & odr & -0.0005841 & 0.0001388 & -4.21 & $0.00 \%$ *** \\
\hline & Ils & -0.0003146 & 0.0000591 & -5.33 & $0.00 \%$ *** \\
\hline \multirow[t]{2}{*}{ dmDEN } & odr & -0.0010891 & 0.0003317 & -3.28 & $0.05 \%$ *** \\
\hline & Ils & 0.0001125 & 0.0001294 & 0.87 & $19.24 \%$ \\
\hline \multirow[t]{2}{*}{ dmWAGEcv } & odr & -0.0031714 & 0.0143935 & -0.22 & $41.28 \%$ \\
\hline & Ils & -0.0152187 & 0.0073483 & -2.07 & $1.93 \%$ *** \\
\hline \multirow[t]{2}{*}{ dmPRNFPcv } & odr & -0.0278520 & 0.0062530 & -4.45 & $0.00 \%$ *** \\
\hline & Ils & -0.0140347 & 0.0025069 & -5.60 & $0.00 \%$ *** \\
\hline \multirow[t]{2}{*}{ geHEtotP } & odr & -0.0160173 & 0.1250571 & -0.13 & $44.91 \%$ \\
\hline & Ils & 0.0092005 & 0.0421378 & 0.22 & $41.36 \%$ \\
\hline \multirow[t]{2}{*}{ geSIZ } & odr & 0.0000145 & 0.0000166 & 0.87 & $19.11 \%$ \\
\hline & Ils & 0.0000114 & 0.0000058 & 1.96 & $2.55 \%$ ** \\
\hline \multirow[t]{2}{*}{ geSIZPf } & odr & 0.0000267 & 0.0000324 & 0.83 & $20.47 \%$ \\
\hline & Ils & 0.0000049 & 0.0000123 & 0.40 & $34.57 \%$ \\
\hline \multirow[t]{2}{*}{ geREGatl } & odr & 0.0041014 & 0.0011744 & 3.49 & $0.03 \%$ *** \\
\hline & Ils & 0.0042574 & 0.0004006 & 10.63 & $0.00 \%$ *** \\
\hline \multirow[t]{2}{*}{ geREGpac } & odr & -0.0081298 & 0.0020384 & -3.99 & $0.00 \%$ *** \\
\hline & Ils & -0.0020239 & 0.0007513 & -2.69 & $0.36 \%$ *** \\
\hline \multirow[t]{2}{*}{ gePOLCgov } & odr & 0.0004209 & 0.0001793 & 2.35 & $0.96 \%$ *** \\
\hline & Ils & -0.0000669 & 0.0000583 & -1.15 & $12.60 \%$ \\
\hline \multirow[t]{2}{*}{$\mathrm{R}^{2}$} & odr & 99.9 & & & \\
\hline & Ils & 97.3 & & & \\
\hline \multirow[t]{2}{*}{$\overline{\ell(\cdot)}$} & odr & -4257.8 & & & \\
\hline & Ils & -5270.8 & & & \\
\hline \multirow[t]{3}{*}{$\overline{\sigma_{\varepsilon}}$} & odr & 103.6 & & & \\
\hline & nls & 638.6 & & & \\
\hline & Ils & 0.0 & & & \\
\hline \multirow{2}{*}{$\sigma_{\varepsilon}$} & odr & 105.9 & & & \\
\hline & Ils & na & & & \\
\hline \multirow{2}{*}{$\sigma_{\mathrm{y}_{\mathrm{t} 0}}$} & odr & 42.8 & & & \\
\hline & Ils & na & & & \\
\hline \multirow{2}{*}{$\sigma_{\varepsilon}$} & odr & 0.00751 & & & \\
\hline & Ils & na & & & \\
\hline
\end{tabular}

*** indicates $\mathrm{H}_{0}$ is rejected at $\alpha=5 \%$ significance level.

** indicates $\mathrm{H}_{0}$ is rejected at $\alpha=10 \%$ significance level.

* indicates $\mathrm{H}_{0}$ is rejected at $\alpha=20 \%$ significance level.

${ }^{a} \ell(\cdot)$ denotes the value of the likehood function. $\left[\sigma_{\varepsilon}, \sigma_{\varepsilon y}, \sigma_{\varepsilon y t 0}, \sigma_{\gamma}\right]$ denotes the standard deviations of the estimated residuals, the measurement error of income, the measurement error for initial income $\mathrm{y}_{0}$, and the model, respectively; the standard deviation $\sigma_{\varepsilon}$ is a weighted average of the measurement error standard deviations and the model standard deviation. 
Table A7: Regression G (per capita; 1977 - 1997)

\begin{tabular}{|c|c|c|c|c|c|}
\hline Variable & Method & Estimate & $\begin{array}{l}\text { Standard } \\
\text { Deviation }\end{array}$ & $\begin{array}{c}t \text {-value } \\
H_{0}: \theta_{i}=0 \\
H_{0}: \theta_{i} \neq 0\end{array}$ & $\begin{array}{c}\text { One-Sided } \\
\text { Marginal } \\
\text { Significance } \\
\text { Level }\end{array}$ \\
\hline \multirow[t]{2}{*}{ usGRW } & odr & 0.7989961 & 0.0352967 & 22.64 & $0.00 \%$ *** \\
\hline & Ils & 0.8324204 & 0.0596820 & 13.95 & $0.00 \%$ *** \\
\hline \multirow[t]{2}{*}{ usINF } & odr & -0.0021219 & 0.0002624 & -8.09 & $0.00 \%$ *** \\
\hline & Ils & -0.0008248 & 0.0002053 & -4.02 & $0.00 \%$ *** \\
\hline \multirow[t]{2}{*}{ usFUELpp } & odr & -0.0047349 & 0.0005882 & -8.05 & $0.00 \%$ *** \\
\hline & Ils & -0.0028951 & 0.0006325 & -4.58 & $0.00 \%$ *** \\
\hline \multirow[t]{2}{*}{ geREGcon } & odr & -0.0097169 & 0.0101706 & -0.96 & $16.98 \%$ \\
\hline & Ils & 0.0143514 & 0.0039682 & 3.62 & $0.02 \%$ *** \\
\hline \multirow[t]{2}{*}{ gePOLstate } & odr & 0.0077890 & 0.0012074 & 6.45 & $0.00 \%^{* * *}$ \\
\hline & Ils & 0.0057615 & 0.0003665 & 15.72 & $0.00 \%$ *** \\
\hline \multirow[t]{2}{*}{$\overline{y_{0}}$} & odr & 0.0043527 & 0.0004827 & 9.02 & $0.00 \%^{* * *}$ \\
\hline & Ils & 0.0015187 & 0.0002343 & 6.48 & $0.00 \%$ *** \\
\hline \multirow[t]{2}{*}{ rho } & odr & 0.0139456 & 0.0018323 & 7.61 & $0.00 \%$ *** \\
\hline & Ils & 0.0125494 & 0.0012713 & 9.87 & $0.00 \%$ *** \\
\hline \multirow[t]{2}{*}{ rvTXTOTAL } & odr & -0.0206724 & 0.0044311 & -4.67 & $0.00 \%$ *** \\
\hline & Ils & -0.0075909 & 0.0022035 & -3.44 & $0.03 \%$ *** \\
\hline \multirow[t]{2}{*}{ rvTXINCcor } & odr & 0.0273090 & 0.0114102 & 2.39 & $0.85 \%$ *** \\
\hline & Ils & 0.0175358 & 0.0047313 & 3.71 & $0.01 \%$ *** \\
\hline \multirow[t]{2}{*}{$\overline{\text { rvTXINCind }}$} & odr & 0.0126408 & 0.0037352 & 3.38 & $0.04 \%$ *** \\
\hline & Ils & 0.0039828 & 0.0015809 & 2.52 & $0.60 \%$ *** \\
\hline \multirow[t]{2}{*}{$\overline{\text { rvTXSALgen }}$} & odr & 0.0164256 & 0.0043098 & 3.81 & $0.01 \%^{* * *}$ \\
\hline & Ils & 0.0067224 & 0.0018590 & 3.62 & $0.02 \%$ *** \\
\hline \multirow[t]{2}{*}{$\overline{\text { rvTXPROP }}$} & odr & 0.0211796 & 0.0048458 & 4.37 & $0.00 \%$ *** \\
\hline & Ils & 0.0062094 & 0.0018675 & 3.32 & $0.05 \%$ *** \\
\hline \multirow[t]{2}{*}{ rvTRFtot } & odr & 0.0346173 & 0.0046416 & 7.46 & $0.00 \%^{* * *}$ \\
\hline & Ils & 0.0081549 & 0.0024853 & 3.28 & $0.05 \%$ *** \\
\hline \multirow[t]{2}{*}{ rvTRFedu } & odr & 0.0547823 & 0.0221364 & 2.47 & $0.68 \%$ *** \\
\hline & Ils & 0.0099688 & 0.0108490 & 0.92 & $17.92 \%$ \\
\hline \multirow[t]{2}{*}{ rvTRFhwy } & odr & -0.0589587 & 0.0197869 & -2.98 & $0.15 \%$ *** \\
\hline & Ils & -0.0327695 & 0.0096035 & -3.41 & $0.03 \%$ *** \\
\hline \multirow[t]{2}{*}{ spEDUtot } & odr & -0.0206737 & 0.0042895 & -4.82 & $0.00 \%$ *** \\
\hline & Ils & -0.0078351 & 0.0021376 & -3.67 & $0.01 \%$ *** \\
\hline \multirow[t]{2}{*}{ spHWYtot } & odr & 0.0033760 & 0.0154022 & 0.22 & $41.33 \%$ \\
\hline & Ils & 0.0438999 & 0.0079969 & 5.49 & $0.00 \%$ *** \\
\hline \multirow[t]{2}{*}{ spWELtot } & odr & -0.0153604 & 0.0050789 & -3.02 & $0.13 \%$ *** \\
\hline & Ils & -0.0014188 & 0.0029730 & -0.48 & $31.67 \%$ \\
\hline \multirow[t]{2}{*}{ spCAPhwy } & odr & -0.0491790 & 0.0167717 & -2.93 & $0.17 \%$ *** \\
\hline & Ils & -0.0783616 & 0.0072578 & -10.80 & $0.00 \%$ *** \\
\hline
\end{tabular}


Table A7: Regression G, continued (per capita; 1977 - 1997)

\begin{tabular}{|c|c|c|c|c|c|}
\hline Variable & Method & Estimate & $\begin{array}{l}\text { Standard } \\
\text { Deviation }\end{array}$ & $\begin{array}{c}t \text {-value } \\
H_{0}: \theta_{i}=0 \\
H_{0}: \theta_{i} \neq 0\end{array}$ & $\begin{array}{c}\text { One-Sided } \\
\text { Marginal } \\
\text { Significance } \\
\text { Level }\end{array}$ \\
\hline \multirow[t]{2}{*}{ dmPOLgov } & odr & -0.0014138 & 0.0008758 & "-1.61 & $5.34 \%$ * \\
\hline & Ils & -0.0004223 & 0.0005660 & -0.75 & $22.79 \%$ \\
\hline \multirow[t]{2}{*}{ dmTXref } & odr & -0.0030315 & 0.0010073 & -3.01 & $0.13 \%$ *** \\
\hline & Ils & -0.0013786 & 0.0004681 & -2.95 & $0.17 \%$ *** \\
\hline \multirow[t]{2}{*}{ dmTXsvl } & odr & 0.0002713 & 0.0000952 & 2.85 & $0.22 \%$ *** \\
\hline & Ils & 0.0000731 & 0.0000348 & 2.10 & $1.79 \%$ *** \\
\hline \multirow[t]{2}{*}{ dmPOP } & odr & -0.0006322 & 0.0001390 & -4.55 & $0.00 \%$ *** \\
\hline & Ils & -0.0003765 & 0.0000566 & -6.65 & $0.00 \% * * *$ \\
\hline \multirow[t]{2}{*}{ dmDEN } & odr & -0.0011308 & 0.0003329 & -3.40 & $0.04 \%$ *** \\
\hline & Ils & -0.0000422 & 0.0001288 & -0.33 & $37.17 \%$ \\
\hline \multirow[t]{2}{*}{ dmWAGEcv } & odr & -0.0127627 & 0.0144083 & -0.89 & $18.80 \%$ \\
\hline & Ils & -0.0256473 & 0.0070387 & -3.64 & $0.01 \%$ *** \\
\hline \multirow[t]{2}{*}{ dmPRNFPcv } & odr & -0.0265801 & 0.0062039 & -4.28 & $0.00 \%$ *** \\
\hline & Ils & -0.0170890 & 0.0025164 & -6.79 & $0.00 \%$ *** \\
\hline \multirow[t]{2}{*}{ geHEtotP } & odr & -0.0110668 & 0.1237472 & -0.09 & $46.44 \%$ \\
\hline & Ils & -0.0019649 & 0.0416799 & -0.05 & $48.12 \%$ \\
\hline \multirow[t]{2}{*}{ geSIZ } & odr & 0.0000182 & 0.0000167 & 1.09 & $13.79 \%$ \\
\hline & Ils & 0.0000138 & 0.0000058 & 2.37 & $0.90 \%$ *** \\
\hline \multirow[t]{2}{*}{ geSIZPf } & odr & 0.0000338 & 0.0000324 & 1.04 & $14.89 \%$ \\
\hline & Ils & 0.0000172 & 0.0000124 & 1.38 & $8.42 \%$ * \\
\hline \multirow[t]{2}{*}{ geREGatl } & odr & 0.0044051 & 0.0011685 & 3.77 & $0.01 \%$ *** \\
\hline & Ils & 0.0041443 & 0.0003931 & 10.54 & $0.00 \%$ *** \\
\hline \multirow[t]{2}{*}{ geREGpac } & odr & -0.0089170 & 0.0020430 & -4.36 & $0.00 \%$ *** \\
\hline & Ils & -0.0032424 & 0.0007670 & -4.23 & $0.00 \% * * *$ \\
\hline \multirow[t]{2}{*}{ gePOLCgov } & odr & 0.0004479 & 0.0001823 & 2.46 & $0.71 \% * * *$ \\
\hline & Ils & -0.0000060 & 0.0000606 & -0.10 & $46.09 \%$ \\
\hline \multirow{2}{*}{$\mathrm{R}^{2}$} & odr & 99.9 & & & \\
\hline & Ils & 97.3 & & & \\
\hline \multirow{2}{*}{$\overline{\ell(\cdot)}$} & odr & -4255.6 & & & \\
\hline & Ils & -5265.6 & & & \\
\hline \multirow[t]{3}{*}{$\overline{\sigma_{\varepsilon}}$} & odr & 104.4 & & & \\
\hline & nls & 634.6 & & & \\
\hline & Ils & 0.0 & & & \\
\hline \multirow{2}{*}{$\sigma_{\varepsilon}$} & odr & 106.7 & & & \\
\hline & Ils & na & & & \\
\hline \multirow{2}{*}{$\sigma_{\varepsilon}$} & odr & 43.3 & & & \\
\hline & Ils & na & & & \\
\hline \multirow{2}{*}{$\sigma_{\varepsilon}$} & odr & 0.00745 & & & \\
\hline & Ils & $\mathrm{Na}$ & & & \\
\hline
\end{tabular}

*** indicates $\mathrm{H}_{0}$ is rejected at $\alpha=5 \%$ significance level.

** indicates $\mathrm{H}_{0}$ is rejected at $\alpha=10 \%$ significance level.

* indicates $\mathrm{H}_{0}$ is rejected at $\alpha=20 \%$ significance level.

${ }^{a} \ell(\cdot)$ denotes the value of the likehood function. $\left[\sigma_{\varepsilon}, \sigma_{\varepsilon y}, \sigma_{\varepsilon y t 0}, \sigma_{\gamma}\right]$ denotes the standard deviations of the estimated residuals, the measurement error of income, the measurement error for initial income $\mathrm{y}_{0}$, and the model, respectively; the standard deviation $\sigma_{\varepsilon}$ is a weighted average of the measurement error standard deviations and the model standard deviation. 